IRSH 53 (2008), pp. I97-233 DOI: I0.1017/S0020859008003428

(C) 2008 Internationaal Instituut voor Sociale Geschiedenis

\title{
Skills, Trust, and Changing Consumer Preferences: The Decline of Antwerp's Craft Guilds from the Perspective of the Product Market, c.I500-c.I 800
}

\author{
BERT De MunCK
}

Summary: The main reason for the decline of craft guilds in Antwerp should not be sought in the labour market but rather in the product market. Apprenticeship systems, master pieces, and trademarks were conducive to a labour market monopsony but at the same time to the representation of product quality. On the one hand, product quality was legitimized through the superior manual skills of masters; on the other, it was objectified through the attribution of quality marks to the characteristics of the raw material used. This strategy was successful for the sale of the durable, expensive, luxury products Antwerp was renowned for until the first half of the seventeenth century, but economic elites and customers stopped favouring corporative regulations when demand shifted towards less expensive and more fashionable products. As guild-based skills were not necessarily superior in reality, and consumer loyalty ultimately depended upon the masters' trustworthiness, the craft guilds were bound to lose credibility.

\section{INTRODUCTION}

The last few decades have seen a dramatic shift in our view of early modern craft guilds, especially with regard to insights about their economic functioning. Most scholars now agree that guilds were not monopolistic in the modern sense of that term. ${ }^{\mathrm{I}}$ Instead of exclusive and rent-seeking cartels, they are seen now as conducive to economic growth. On the labour market, restricting the group of employers eligible to use skilled labour (installing a "labour-market monopsony") encouraged masters to invest in training and promoted the formation of human capital. ${ }^{2}$ On the product

I. Gary Richardson, "A Tale of Two Theories: Monopolies and Guilds in Medieval England and Modern Imagination”, Journal of the History of Economic Thoughts, $23: 2$ (2001), pp. 217-242; idem, "Guilds, Laws, and Markets for Manufactured Merchandise in Late Medieval England", Explorations in Economic History, 4I (2004), pp. I-25.

2. Stephen R. Epstein, "Craft Guilds, Apprenticeship, and Technological Change in PreIndustrial Europe”, Journal of Economic History, 58 (1998), pp. 684-71 3; Richardson, "A Tale of Two Theories", p. 237. 
market, standardizing products, guaranteeing product quality, and applying trade marks enabled masters to respond to price competition with niche products and high quality. Craft guilds prescribed master pieces, visits by guild officials, fines to prevent fraud, and the application of trademarks in order to differentiate the products of guild-based masters and to cultivate brand loyalty (their so-called "monopolistic competition"). ${ }^{3}$

As a result of the concentration on the more "positive" aspects of the guild system, research on their final demise has been neglected. ${ }^{4}$ Traditional scholarship has tended to characterize a simplistic dichotomy: "powerful" guilds stifling innovation in southern Europe from the late Middle Ages onward, contrasted with the subsequent economic vitality of countries (i.e. the Netherlands and England), where a much "weaker" guild system existed.5 In recent textbooks on the early modern economy, seventeenth- and eighteenth-century craft guilds are rarely mentioned. ${ }^{6}$ When they do receive consideration, they continue to be interpreted either as powerful bodies blocking innovation, ${ }^{7}$ or otherwise as anachronistic institutions impotent in the face of the growing dynamism of protoindustrialization and industrialization. ${ }^{8}$

Authors addressing their decline explicitly often relate it to the rise of labour market flexibility, resulting from either demographic and labourmarket changes effectively removing the guilds' barriers to labour-market entry, ${ }^{9}$ or, more often, because merchants and entrepreneurs increasingly

3. John R. Munro, "Urban Regulation and Monopolistic Competition in the Textile Industries of the Late-Medieval Low Countries", in Erik Aerts and John R. Munro (eds), Textiles of the Low Countries in European Economic History (Leuven, 1990), pp. 4I-50; idem, "Medieval Woollens: The Western European Woollen Industries and their Struggles for International Markets, c.1000-1 500", in David Jenkins (ed.), The Cambridge History of Western Textiles, I, (Cambridge, 2003), pp. 228-324, 378-86 (ch. 5); Bo Gustafsson, "The Rise and Economic Behaviour of Medieval Craft Guilds", in idem (ed.), Power and Economic Institutions. Reinterpretations in Economic History (Aldershot, I99I), pp. 69-106.

4. For a state of the art, see Heinz-Gerhard Haupt (ed.), Das Ende der Zünfte. Ein europäischer Vergleich (Göttingen, 2002).

5. See for example Carlo M. Cipolla, “The Economic Decline of Italy”, in Brian Pullan (ed.), Crisis and Change in the Venetian Economy (London, I 968), pp. I 27-I45, I35; also Jan de Vries and Ad van der Woude, The First Modern Economy: Success, Failure, and Perseverance of the Dutch Economy, I500-I8IS (Cambridge, 1997).

6. See for example Peter Kriedte, Peasants, Landlords and Merchant Capitalists: Europe and the World Economy, I500-I 800 (Cambridge, I983); Peter Musgrave, The Early Modern Economy (Basingstoke, 1999).

7. Ibid., pp. 71-73, 89, I33. Also Carlo M. Cipolla, Before the Industrial Revolution: European Society and Economy, 1000-1700 (London, 1976), pp. 239-244.

8. Robert. S. Duplessis, Transitions to Capitalism in Early Modern Europe (Cambridge, 1997), Pp. 35-36, IIO, II 3, II 8, I 20-I2I, I26-I 28,225 .

9. Steven L. Kaplan, "L'apprentissage au XVIIIe siècle: le cas de Paris", Revue d'histoire moderne et contemporaine, 40 (1993), (special number on Apprentissages XVIe-XXe siècles), pp. $436-479,436$, assumes that craft guilds were ultimately "flooded" by the labour market, arguing metaphorically that, thanks to the guilds, “la communauté n’est pas complètement débordée par 
evaded guild regulations relating to workshop size and apprenticeship terms - redirecting production to the countryside or the city's suburbs. ${ }^{10}$ This, of course, conflicts with perceiving guilds as institutions that encouraged investments in human capital and product innovation rather than as monopolistic and rent-seeking cartels. Questions arise as to when, why, and for whom craft guilds were (perceived as being) superfluous or cumbersome.

From an ideological perspective, eighteenth-century guilds appeared in the context of an opposition of local political forces against both the growing impact of state formation and the economic rationale of enlightened reformers. ${ }^{\text {II }}$ Whether French or Scottish, the reformers in question were not only associated with labour-market flexibility and economies of scale, they referred to a common good that surpassed the city the guilds were imbedded in. Yet, instead of seeing this in a framework of politics versus economics, we should focus upon the cultural and ideological motivations of both the guild boards and their opponents. While state formation was certainly an important aspect of the rising opposition to city-based corporative regulations, the declining power of guilds to legitimize their "privileges" against the claims of other (economic) actors is in need for a more comprehensive analysis. ${ }^{\mathrm{I}}$

After all, the guilds' strategies were invariably linked to honour, privilege, and guarding a certain "état", ${ }^{13}$ suggesting that the discussions between guild-based masters and their opponents should be approached from the perspective of qualifications and the perception of competencies.

ce que nous appelons le marché" [the community is not completely inundated by what we call the market].

Iо. Steven L. Kaplan, "Les corporations, les 'faux ouvriers' et le faubourg Saint-Antoine au XVIIIe siècle", Annales ESC, 43 (1988), pp. 353-378; Liana Vardi, "The Abolition of the Guilds during the French Revolution”, French Historical Studies, Is (1988), pp. 704-717; Duplessis, Transitions to Capitalism, pp. 230-255. In England, the decline of statutory apprenticeship in the eighteenth century is to be considered. Cf. K.D.M. Snell, Annals of the Labouring Poor: Social Change and Agrarian England, 1660-1900 (Cambridge, I985), pp. 228-269.

I I. Cf. e.g. Josef Ehmer, “Zünfte in Österreich in der frühen Neuzeit”, in Haupt, Das Ende der Zünfte, pp. 87-126, г г2-г26; Daniela Frigo, "Die italienischen Zünfte am Ende des Ancien Régimes: Stand, Probleme und Perspektiven der Forchung”, in ibid., pp. 197-214, 208-214; Corine Maitte, "Le réformisme éclairé et les corporations: l'abolition des Arts en Toscane", Revue d'histoire moderne et contemporaine, 49 (2002), pp. 56-88.

I 2. From a political point of view, discourses associated with the guilds (republicanism and communalism) are seen even now as lying at the root of the first parliamentary and constitutional democracies; Peter Blickle, "Kommunalismus, Parlamentarismus, Republikanismus", Historische Zeitschrift, 242 (1986), pp. 529-556; Quentin Skinner and Martin Van Gelderen, Republicanism: A Shared European Heritage (Cambridge, 2002), 2 vols.

I3. William H. Sewell, Work and Revolution in France: Language of Labor from the Old Regime to 1848 (Cambridge, 1980), pp. 190-19I; Steven L. Kaplan, "Social Classification and Representation in the Corporate World of Eighteenth-Century France: Turgot's 'Carnival'”, in idem and Cynthia Koepp (eds), Work in France: Representations, Meaning, Organization, and Practice (Ithaca, NY, 1986), pp. 176-228. 
In my opinion, the answer lies in the relationship between economic and cultural factors. Although "honour", "status", and "privilege" have long been associated with corporative inertia, market segmentation, and an intransigent society of orders, cultural factors are beginning to explain how guilds encouraged economic growth. Trust and reputation, for example, are seen as incentives for fulfilling contracts and social networks as important assets in making information available and reliable. ${ }^{\mathrm{I}}$ However, considered from a broader perspective - including the perception of skills and product quality - cultural factors may also explain the eventual demise of craft guilds.

In this article - analysing the regulations of a sample of guilds, ${ }^{15}$ followed by a comparison with recent literature on changing consumer preferences - I shall argue that the decline of the Antwerp craft guilds should be understood from the perspective of the cultural value (standards, conventions) attributed to their products. In the first section, the role of labour-market regulations will be reconsidered. Far from seeing increasing quantities of cheap and unskilled labour "flooding" the market and overwhelming traditional guild regulation, ${ }^{16}$ it is proposed here that craft guilds, in fact, struggled with problems related to the "reproduction" of

I4. See, among others, Avner Greif, Paul Milgrom and Barry R. Weingast, "Coordination, Commitment and Enforcement: The Case of the Merchant Guild”, in Jack Knight and Itai Sened (eds), Explaining Social Institutions (Ann Arbor, MI, I995), pp. 27-56; Ulrich Pfister, "Craft Guilds and Proto-Industrialization in Europe, i 6th to I 8th centuries”, in E.C. Nunez (ed.), Guilds, Economy and Society, Proceedings B I, Twelfth International Economic History Congress, Madrid (Seville, 1998), pp. I I-25; Richardson, "A Tale of Two Theories"; Philippe Minard, "Les corporations en France aux XVIIIe siècle: métiers et institutions”, in Steven L. Kaplan and Philippe Minard (eds), La France, malade du corporatisme? XVIIIe-XXe siècles (Paris, 2004), pp. 39-5I; Peter Stabel, "Guilds in Late Medieval Flanders: Myths and Realities of Guild Life in an Export Oriented Environment”, Journal of Medieval History, 30 (2004), pp. I87-2 I 2.

I 5. Carpenters, cabinetmakers, gold and silversmiths, tinsmiths and plumbers, tanners and shoemakers, and (to a lesser degree) cloth dressers and diamond cutters will be examined in detail. Other crafts will be included via existing studies, the most important of which are Alfons K.L. Thijs, Van "werkwinkel" tot "fabriek". De textielnijverbeid te Antwerpen (einde Is debegin I9de eeuw) (Brussels, 1987) for the textile sector, and Harald Deceulaer, Pluriforme patronen en een verschillende snit. Sociaal-economische, institutionele en culturele transformaties in de kledingsector in Antwerpen, Brussel en Gent, I585-I800 (Amsterdam, 200I) for the garment industry. As they were in the vanguard in institutionally substituting the apprenticeship system (by the Medical College in I62I and by the Art Academy in 1663), the medical professions and artistic trades will be considered as well. See Bert De Munck, "Le produit du talent ou la production de talent? La formation des artistes à l'Académie des beaux-arts à Anvers aux XVII ${ }^{\mathrm{e}}$ et XVIII ${ }^{\mathrm{e}}$ siècles", Paedagogica Historica, 37 (200I), pp. 569-607; and idem, "Medische praktijken. Conflicten rond competentie in de Antwerpse medische sector, I7de en I8de eeuw", Tijdschrift voor Sociale Geschiedenis, 27 (200I), pp. 459-484.

I6. The image is very much based on research on booming cities such as London and Vienna and does not apply to the declining metropolis, Antwerp. Cf. Joan Lane, Apprenticeship in England, 1600-1914 (London, 1996); Annemarie Steidl, Auf nach Wien! Die Mobilität des mitteleuropäischen Handwerks im I8. und 19. Jahrhundert am Beispiel der Haupt- und Residenzstadt (Munich, 2003). See also Steven L. Kaplan, La fin des corporations (Paris, 200I). 
adequate numbers of new journeymen and even masters, suggesting that the attractiveness of craft guilds was becoming problematic.

In the second section the focus shifts from labour-market regulations to the apprenticeship system and its relation to skills. In theory, apprenticeship could both produce superior technical skills and enhance product quality, but examining guild ordinances closely reveals other features. The apprenticeship system (i.e. a fixed duration and the obligation to make a master piece) first of all defined who was authorized to make the product involved. This is, of course, related to product quality, but in the third section we will see that product quality was not directly related to the superior technical abilities of guild-based artisans (those having finished an apprenticeship term and having successfully completed and submitted a master piece). Product quality was rather objectified via quality marks referring to the quality of the raw materials used and, therefore, to the individual master's trustworthiness and integrity.

Nor were the manual skills of guild-based artisans in themselves verifiably superior: the claim to craftsmanship was in fact a representational asset. As a result, the apprenticeship system, of which the right to use a trademark was the defining outcome, should be understood as a system for legitimizing the social status of "mastership". Master status was essential for defining product quality, but at the same time it enabled small and large masters alike to preserve the status and market value of their manual skills and - in the end - to legitimize their labour-market monopsony.

This strategy proved feasible in situations where a burgeoning demand existed for high value-added products, and where customers appreciated the need for detailed information on the "quality" and "craftsmanship" embodied in complex pieces of work - as was the case in Antwerp until the first half of the seventeenth century. ${ }^{17}$ When consumer demand shifted to cheaper and more fashion-sensitive products during the seventeenth and eighteenth centuries, ${ }^{18}$ however, this approach became more difficult to

17. Herman van der Wee, The Growth of the Antwerp Market and the European Economy (Fourteenth-Sixteenth Centuries) (The Hague, 1963), 2 vols; Bruno Blondé and Michael Limberger, "De gebroken welvaart", in Geschiedenis van Brabant, van het hertogdom tot heden (Leuven, s.d.), pp. 307-3 I I; Ilja Van Damme, "Het vertrek van Mercurius: historiografische en hypothetische verkenningen van het economisch wedervaren van Antwerpen in de tweede helft van de zeventiende eeuw", NEHA-Jaarboek voor economische, bedrijfs-en techniekgeschiedenis (2003), pp. 6-39.

18. See, among others, Neil McKendrick, John Brewer, and J.H. Plumb (eds), The Birth of a Consumer Society: The Commercialization of Eighteenth-Century England (London, 1982); John Brewer and Roy Porter (eds), Consumption and the World of Goods (London [etc.], I993); Ann Bermingham and John Brewer (eds), The Consumption of Culture, 1600-I800: Image, Object, Text (London [etc.], I995). For Antwerp, see Deceulaer, Pluriforme patronen, $200 \mathrm{I}$ (ch. 5); Bruno Blondé, "Tableware and Changing Consumer Patterns: Dynamics of Material Culture in Antwerp, 17th-18th centuries", in Johan Veeckman (ed.), Majolica and Glass from Italy to Antwerp and Beyond: The Transfer of Technology in the 16th-Early I7th Century (Antwerp, 2002), pp. 295-3II; Ilja Van Damme, "Changing Consumer Preferences and Evolutions in 
maintain. As cheaper substitutes increasingly permeated the markets, the importance assigned by merchants, retailers, and consumers to both the quality of the raw materials used and the level of manual skills became less critical. At the same time, state formation must have complicated perpetuating the distinction between guild-based (and thus city-based) products from others. New, often imported, products supplied by merchants and retailers demonstrated the growing appeal of effective product design in combination with low prices, two areas where guilds unquestionably compared poorly with their competitors. As a result, in addition to guild-based masters losing market power, many merchants were no longer inclined to use the craft guilds to achieve their aims. As a result, the corporative privileges or monopolies were soon perceived as untenable.

All this will be examined for Antwerp, a pivotal city in the shift of the economic centre of gravity from the Mediterranean to the Atlantic. Recent scholarship has suggested that craft guilds and merchant capitalism were far from mutually exclusive, and that urban craft guilds responded rather successfully to "proto-industrialization" within the countryside through a combination of product innovation and monopolistic competition. ${ }^{19}$ Yet the decline of the guilds in the southern Netherlands has yet to be re-examined in light of the new scholarship. Their eventual abolition often continues to be attributed to internal sclerosis, reflected in their abortive attempts to maintain an oligarchic closure in the eighteenth century. ${ }^{20}$ Nonetheless,

Retailing: Buying and Selling Consumer Durables in Antwerp (c.1648-c.1748)", in Bruno Blondé, Peter Stabel, Jon Stobart and Ilja Van Damme (eds), Buyers and Sellers: Retail Circuits and Practices in Medieval and Early Modern Europe (Turnhout, 2006), pp. 199-223; Bruno Blondé and Ilja Van Damme, "Een crisis als uitdaging? Kleinhandelsevoluties en verbruiksveranderingen te Antwerpen (ca.I648-ca.1748), Tijdschrift voor sociale en economische geschiedenis, 4 (2007), pp. 6I $-88,66-76$.

19. Herman Van Der Wee, "Industrial Dynamics and the Process of Urbanization and DeUrbanization in the Low Countries from the late Middle Ages to the Eighteenth Century", in idem (ed.), The Rise and Decline of Urban Industries in Italy and the Low Countries (Late Middle Ages-Early Modern Times) (Leuven, I988), pp. 307-381; Catharina Lis and Hugo Soly, "Different Paths of Development: Capitalism in the Northern and Southern Netherlands during the Middle Ages and the Early Modern Period", Review, 20 (1997), pp. 21 I-242; idem, "Exportgewerbe, Zünfte und kapitalistische Entwicklungen in den Nördlichen und Südlichen Niederlanden im späten Mittelalter und der Frühen Neuzeit", in Wilfried Reininghaus (ed.), Zunftlandschaften in Deutschland und den Niederlanden im Vergleich (Wesfalen-Lippe, 2000), (Schriften der Historischen Kommission für Westfalen), pp. 45-70. Specifically for Antwerp: Alfons K.L. Thijs, “Antwerp's Luxury Industries: The Pursuit of Profit and Artistic Sensitivity”, in Jan Van Der Stock (ed.), Antwerp, Story of a Metropolis, I6th-I 7 th Century (Antwerp, 1993), pp. I05-I I3. For a quantitative analysis of the incidence of craft guilds, see Bert De Munck, Piet Lourens, and Jan Lucassen, "The Guilds in the Northern and the Southern Netherlands: A Comparative Perspective", in Catharina Lis, Jan Lucassen, Maarten Prak, and Hugo Soly (eds), Craft Guilds in the Early Modern Low Countries: Work, Power and Representation (London, 2006), pp. 32-73.

20. Hubert Van Houtte, Histoire économique de la Belgique à la fin de l'Ancien Régime (Ghent, I920), pp. 54-I I6. 
overt hostility towards craft guilds seems to have emerged in the course of the seventeenth century at the very latest. ${ }^{21}$ We therefore need to establish the course of events between the "takeover" of Antwerp in the "long sixteenth century" and the definitive transformation of the corporative structures in the second half of the eighteenth century, when mercantile and industrial elites had joined forces in their "crusade" against corporative privilege. ${ }^{22}$

\section{LABOUR-MARKET REGULATION}

Labour-market regulation has often been understood as the determining feature of the craft guilds. One particularly important aspect of the overall system was to limit the ratio of apprentices and journeymen employed by master craftsmen. As Catharina Lis and Hugo Soly have argued, regulations about the number of journeymen per master resulted from specific labour relations within different sectors. At least in the export industries (especially textiles), merchants and small masters often joined efforts to limit workshop size. Merchants typically tried to prevent competition from large masters and, at the same time, to maintain networks of small masters available for their "putting-out" systems to operate. In the southern Netherlands, however, this strategy did not prevail in the long term. ${ }^{23}$ Large masters, who strived for large numbers of employees, often successfully deregulated restrictions on workforce size. Good examples of this have been found in the trade of cloth dressing and the silk industry. As a result, small masters often experienced the risk of having to work directly for large masters as piece workers, as is demonstrated by the fortunes of many linen weavers in the seventeenth century. ${ }^{24}$ The decline of the craft guilds, from this perspective, would be related to concentration of production. ${ }^{25}$

However, the strategies of the small guild-based masters entailed more than simply restricting the size of workshops. Nor should small and large

21. At least in the northern Netherlands; cf. Jan Lucassen, "Het Welvaren van Leiden (I659I662): de wording van een economische theorie over gilden en ondernemerschap", in Boudien de Vries et al. (eds), De kracht der zwakken (Amsterdam, I992), pp. I3-48; Karel Davids, "From De La Court to Vreede: Regulation and Self-Regulation in Dutch Economic Discourse from c. 1600 to the Napoleontic Era", Journal of European Economic History, 30 (200I), pp. 245-289. 22. Cf. Jean-Jacques Heirwegh, "Les corporations dans les Pays-Bas autrichiens (1738-1784)", (unpublished doctoral thesis, Université Libre de Bruxelles, I98I).

23. Catharina Lis and Hugo Soly, "Ambachtsgilden in vergelijkend perspectief: de Noordelijke en de Zuidelijke Nederlanden, Isde-i8de eeuw", in idem (eds), Werelden van verschil. Ambachtsgilden in de lage landen (Brussels, 1997), pp. 17-18; idem, "Different Paths of Development"; idem, "Export Industries, Craft Guilds and Capitalist Trajectories", in Lis, Lucassen, Prak, and Soly, Craft Guilds in the Early Modern Low Countries, pp. I 19-123.

24. Thijs, Van "werkwinkel" tot "fabriek", pp. 219-257. See also Deceulaer, Pluriforme patronen, pp. I44-I45.

25. Cf. Catharina Lis and Hugo Soly, "Die Zünfte in den Österreichischen Niederlanden", in Haupt, Das Ende der Zünfte, pp. I55-180. 
masters always be seen as mutual rivals. Guild-based masters, both small and large, could often be seen rallying support for craft ideals against the entry of merchants into their ranks. In the sixteenth century, admittedly, restrictions on workshop size were significantly relaxed. ${ }^{26}$ In 1477 , for example, the Guild of Shoemakers stipulated that masters were permitted to manage only one workbench and one stall. ${ }^{27}$ By I600, it was ruled that masters could employ up to six journeymen, in addition to their own children. ${ }^{28}$ In another example, in 4997 the Guild of Cabinetmakers ruled that a master could employ only one journeymen and one apprentice, ${ }^{29}$ but by I I I9, after initial suggestions that masters might employ "ten, twelve or even more workers", negotiations finally confirmed that up to six workers - including an apprentice - could actually be employed by a single master. ${ }^{30}$ Even this limit was easily circumvented afterwards. ${ }^{3 \mathrm{I}}$

Given the economic expansion of the sixteenth century, it is easy to imagine that craft guilds adapted their regulations pragmatically to a changed reality. In other guilds, however, this pragmatic adaptation seems to have been unnecessary, as was the case with the pewterers. In ${ }_{4} 42$ pewterers were allowed to have two apprentices and only one stall (kraam), ${ }^{32}$ and these rules remained fundamentally unchanged thereafter perhaps as a result of the determining influence of merchants or mercers in the trade. In trades such as the gold and silversmiths and the tailors on the other hand, corporate prohibitions on the employment of journeymen even unfree journeymen - were absent altogether. ${ }^{33}$ This would, in theory,

26. Lis and Soly, "Export Industries", p. I I9.

27. City Archives Antwerp (hereafter CAA), Guilds and Trades (hereafter GT) 4II2, 3 December I477, fo. 39r-43v, arts I6 and 33; GT 4I I2bis, p. 50 (copy).

28. CAA, GT 4I I 2, 24 November I603, fos 86v-87v; GT 4I I 2, 30 January i606, fos 94v-95r.

29. CAA, GT 4334, fo. Iff; GT 4335, I 4 June I 497 , fo. $2 \mathrm{v}$.

30. CAA, GT 4334, fo. 22; GT 4335, 24 December I 519 , fo. $26 \mathrm{vff}$.

3i. CAA, GT 4334, fo. 22v; GT 4335, 4 June I 522. See also GT 4334, fos 7ir-72v; GT 4335, 25 March I62I, fos $92 \mathrm{v}-94 \mathrm{r}$.

32. J. Van Deun, "Het Antwerpse tinnegietersambacht in het Ancien Régime", in Keur van tin uit de havensteden Amsterdam, Antwerpen en Rotterdam (Amsterdam [etc.], 1979), pp. 40-42. 33. In their founding ordinance in 1454 the gold and silversmiths explicitly stated "that all good alien journeymen, wherever they come from, who want to earn their living in Antwerp, with a master for a daily wage, by contract or by piece, should be allowed to do so without further due"; Ordinance 24 February I454, art. 2, published in P. Génard, "Notice sur la corporation des orfèvres d'Anvers", Annales de l'Académie d'Archéologie de Belgique, 45, 4e series, Tome V, pp. 3I2-317 [hereafter Ordinance 24 February I454]. In an ordinance of I574, it was stated that unfree journeymen could work for a regular master, provided that they worked and lived under his roof; CAA, GT 4002, 22 November I 574 , fo. 65 r (see also GT 4485, no. 3, fo. I4v). The diamond cutters stipulated in their founding ordinance of 1582 that "every alien journeyman wanting to work here will have to do it with a free master and when asked have his name written down at the guild chamber within three days"; Ordinance 25 October 1582, published in D. Schlugleit, Geschiedenis van het Antwerpsche diamantslijpersambacht (Antwerp, 1935), p. 16, art. 25 [hereafter Ordinance 25 October I582]. The shoemakers had a similar ruling in 1606; CAA, GT 4I I 2, 30 January I 606, fos 94v-95; GT 4I I 2, fos 86v-87v, 24 November I603. In the 
suggest that the influence of large masters, whether they continued to use subcontracting or preferred the use of larger workshops, was dominant within the guild. The question remains, nevertheless, when and under what conditions such regulations were a key feature of guild regulations.

In my opinion, at least after 1585 , regulation of workshop size was not the primary focus. The above-mentioned ordinance of the pewterers in I442, for example, also stipulated that master pewterers were allowed to sell only their own wares on stalls. ${ }^{34}$ Could protecting master status from sub-contracting or the threat of a possible separation of production and retail perhaps have been more important? In most trades, in any case, the ceilings on employment that came into existence between the end of the fifteenth century and the end of the sixteenth century were not challenged thereafter. ${ }^{35}$ Was labour perhaps too scarce in the seventeenth and the first half of the eighteenth centuries, especially skilled labour?

Even in the textile and construction sector, where discussions about this issue did re-emerge, ${ }^{36}$ the precise nature of the challenge remains unclear. In 1756, following their merger with the Guild of Carpenters, the cabinetmakers complained about the number of journeymen that carpenters would often engage. In this merged guild, the maximum permitted ratio of directly employed workers was raised from six to twelve per master, but some carpenters circumvented even this. ${ }^{37}$ The main point of contention between these groups, however, did not relate specifically to workshop size. Rather, the problem seems to have been that carpenters had developed a tradition of hiring cabinetmakers' journeymen and apprentices during production peaks, depriving these masters of their workforce..$^{8}$

The absence of prolonged conflict over the regulations governing

garment industry restrictions on workshop size were rare. For the hosiery makers and the tailors, there is evidence that masters employed unfree workers, who sewed from their own homes; Deceulaer, Pluriforme patronen, pp. I09, I37, I44-I45, 300.

34. Van Deun, "Het Antwerpse tinnegietersambacht", pp. 40-42; CAA, GT 4264, I March I 545 (I546).

35. In the sixteenth century, master cloth dressers tried to circumvent ceilings on the number of employees and workbenches ("scheerdissen"), registering them under their sons' names (registering the latter in turn as masters). Preventing this, the guild prescribed a minimum age for master sons; CAA, GT 4029, 7 October I 536, art. 9 (extract); GT 4028, I 3 May is62, pp. $53-54$. Regulations like these mostly lacking in the seventeenth and eighteenth centuries.

36. Thijs, Van "werkwinkel" tot "fabriek", pp. 219-257; Deceulaer, Pluriforme patronen, pp. I62-I63; Bert De Munck, "Meritocraten aan het werk. Deregulering van de arbeidsmarkt bij de Antwerpse timmerlieden in de I8de eeuw", in Bruno Blondé, Bert De Munck, and Filip Vermeylen (eds), Doodgewoon. Mensen en hun dagelijks leven in de geschiedenis. Liber Amicorum Alfons K.L. Thijs (Antwerp, 2005), (Bijdragen tot de geschiedenis, 87 (2004), I-2), pp. 87-106.

37. CAA, GT 4345, 6 July 1756, art. 27; GT 4345, I6 July 1756, fo. Ioff; GT 4345, fo. 26-26v. 38. CAA, GT 4004, i 3 April r66o, fos 8 Iv-82r; GT 4334, fos 88-88v; GT 4335, fos i I4v-i is (copy); GT 4335, 9 December I743, fo. I $34 \mathrm{v}$ ff. 
workforce size may have been attributable in part to the presence of more pragmatic alternatives, such as subcontracting and Kaufsystems, if not to the absence of regulation altogether. From the seventeenth century on, in any case, most guilds seem to have been preoccupied with other concerns. A regulation that did exist (and was continued) in most craft guilds, was the one regarding the maximum number of new apprentices. In 1477 the Guild of Shoemakers ruled that small masters could hire only one apprentice at the time. ${ }^{39}$ Once again, by about 1600 , this ruling had been relaxed. Henceforth, small masters could hire one apprentice every year, so that two apprentices could work in each workshop (as apprenticeship terms lasted two years). ${ }^{4}$ A similar trend existed with the Guild of Cabinetmakers. In I 497 they proposed, as the length of apprenticeship in this craft was three years, that an individual master could hire a new apprentice every three years. ${ }^{41}$ In 1606 , it was ruled that every master could hire a new apprentice from the moment the latter had served one year and nine months of the two-year apprenticeship..$^{2}$ With this relaxation of the rules, the turnover of apprentices increased, suggesting either that masters wanted to expand the supply of available journeymen or that large entrepreneurs and merchants wished to enlarge the number of masters. ${ }^{43}$

After I600, however, no further rulings concerning either the number of apprentices or the length of their apprenticeship term were issued in most trades. ${ }^{44}$ In this case, the progressive disinterest in new labour-market regulations was due not to the presence of options other than increasing workshop size (or the lack of power among groups that had an interest in regulating workshop size - for instance journeymen, cf. infra) but to the fact that workshops rarely reached the maximum size in the seventeenth and eighteenth centuries. In the Coopers' Guild, for example, between the end of the sixteenth century and the final decades of the eighteenth century, the number of new apprentices declined both in absolute numbers and in relation to masters. Over this period, the ratio of new apprentices to new masters fell from more than four to one to approximate parity. ${ }^{45}$ Similar trends have been identified for the shoemakers in Brussels, where the relative number of new

39. CAA, GT 4i i 2, 3 December i 477, fo. 39 r ff, arts I6 and 33; GT 4 I I 2bis, p. 50 (copy).

40. CAA, GT 4I I 2, 24 November I603, fos 86v-87v; GT 4I I 2, 30 January I606, fos 94v-95r.

4I. CAA, GT 4334, fo. Iff; GT 4335, I4 June I 497, fo. 2v. The gold and silversmiths had a similar rule in I 524 ; CAA, GT 4488 , fo. I I 5 r, 24 November i 524 , art. 8.

42. CAA, GT 4334, fos 56v-58v; GT 4335, 20 November I606, $73 \mathrm{v} \mathrm{ff}$.

43. In I 497 a master was not allowed to hire a new apprentice when he agreed to acquit the contract of the apprentice he had. This implies that the maximum number of apprentices regulated the number of new journeymen or (more likely) the number of new masters, instead of, for instance, the quality of training.

44. There were of course exceptions, for example in the silk industry, where journeymen and small masters protested against masters engaging more apprentices than allowed (two in their case) in I684. Thijs, Van "werkwinkel" tot "fabriek", p. 400.

45. CAA, GT 4I83, GT 4I 84 and GT 4I85, account books of the Coopers' Guild. 
apprentices declined from five per new master in the early decades of the seventeenth century to one per new master in the second half of the eighteenth century (the total number of new masters being rather stable). ${ }^{46}$

In the craft guilds examined in this article, the relatively short durations of apprenticeships (two or three years in most cases) were conducive to a high turnover of apprentices only in theory. The possible turnover remained unrealized in most crafts. Between I 7 I I and I790, for example, there was an average of at least thirty master pewterers and plumbers - forming one guild - who were economically active in Antwerp. Each master was allowed to engage two apprentices with an apprenticeship period lasting two years in all. ${ }^{47}$ In 80 years, then, they could theoretically hire up to 2,400 apprentices, but in practice they only employed a total of $255.4^{8}$ Shoemakers, who prescribed apprenticeship periods of two years and no more than one apprentice per master at once, ${ }^{49}$ could theoretically hire about 68 apprentices per year (as an average of I 36 masters paid annual dues); yet they registered only I 4 apprentices a year on average between 1765 and $1793.5^{\circ}$

In theory, this could mean that there was a lack of work, but in practice Antwerp, or rather some guild-based industries in Antwerp, seem to have ceased to appeal to unskilled youths wanting to learn a trade. After I 585 guild masters devised a range of strategies to cope with a lack of appeal. A decrease in the number of apprentices might coincide with a parallel increase in the number of masters' sons learning their fathers' trades. ${ }^{51}$ In Antwerp this strategy is not discernible, as the trend was to register only the eldest son - the one destined to succeed the father - as an apprentice. ${ }^{52}$ However, it can be argued that craft guilds adopted inclusive strategies.

First, the period of indenture was relatively short in Antwerp, being typically two years in length (longer than four years was exceptional). Second, master pieces did not become more complicated in the early modern period. On the contrary, the master trial of the cabinetmakers

46. Ilse Salien, “'Op de leest geschoeid'. Sociaal-economische geschiedenis van het oude en nieuwe schoenmakersambacht te Brussel in het Ancien Régime" (unpublished licentiate thesis, Vrije Universiteit Brussel, 1999), pp. 51-53.

47. Van Deun, "Het Antwerpse tinnegietersambacht", pp. 40-42; CAA, GT 4264, I March I 543 (I 544); CAA, Privilegiekamer [hereafter PK] 710, 5 February i6 18, fos I07r-107v.

48. CAA, GT 424I, "Boeck der opgeschreven incomelingen in het hooftambacht vande Meersche" (I7II-I794).

49. CAA, GT 4I I 2, I6 November I 394 (I395), fo. 7 Ir; CAA, GT 4I I 2, 3 December I477, fos 39r-43v, arts I6 en 33; GT 4 I I 2bis, p. 50, (copy).

50. CAA, GT 4I 2 I, account book of the Shoemakers' Guild.

5. As was, for example, the case in the Guilds of Carpenters, Wood-Cutters and Millers in Leuven, especially after 1770; Marina Laureys, "Bijdrage tot de sociale geschiedenis van het Leuvense ambachtelijke milieu. Het ambacht van de timmerlieden, de houtbrekers en de molenmakers (1700-1795)" (unpublished licentiate thesis, K U Leuven, I980), pp. I29-I32.

52. Bert De Munck, Technologies of Learning: Apprenticeship in Antwerp from the Is th Century to the End of the Ancien Régime (Turnhout, 2007), ch. 4.2. 
evolved from three pieces (two different cabinets and a table) in I497 to one (a sideboard) in I 543.53 Carpenters first had to make a master piece as a prospective journeyman and then another as a prospective master, but the first trial ceased to be required in the seventeenth and eighteenth centuries. ${ }^{54}$ And whereas tinsmiths in I 523 first had to make the mould to cast their pot, they could borrow one from the guild in 1705.55 In addition to becoming simpler, moreover, the master piece became cheaper. In the I740s, for example, the Guilds of Cabinetmakers and of Coopers compensated for their higher fees by prescribing a less ornate master piece. The new pieces required cheaper raw materials and less time to produce and were easier to sell as well. ${ }^{56}$

Third, and most importantly, financial barriers were kept as low as possible. The increases to registration and admission fees during the course of the seventeenth and eighteenth centuries were involuntary. ${ }^{57}$ Most craft guilds actually introduced a range of measures to attract new apprentices and masters. Increased registration fees, for example, could later be deducted from the admission fee for guild membership, thus preserving the incentive to become a master, at least for regular apprentices. The cabinetmakers were the most radical here.$^{8}$ As early as 4497 the registration fee (to be paid by new apprentices) could be deducted from the admission fee (to be paid by new masters). In addition, those who had completed their apprenticeship were prohibited from engaging in any other trade. 59

53. CAA, GT 4334, fo. Iff; GT 4335, I 4 June I 497 (copy); CAA, GT 4334, fos 3 I-33; GT 4335 , 3 I March I 543 (I 544 ) (copy).

54. CAA, GT 434I, 3 I March i 543, arts 5-6; GT 4345, 6 July i756, fo. 9ff, arts 3-4.

55. CAA, GT 4264, I 2 November I 523; GT 4264, 25 June 1705 .

56. CAA, GT 4337, 6 November I745, fo. 39, art. I 3 ; Bart Willems, "Loon naar werken? Sociale mobiliteit in het Antwerpse kuipersambacht (1585-1793)", Bijdragen tot de Geschiedenis, 82 (1999), pp. 40-44. It is not always clear whether guilds tried to lower entrance barriers at their own initiative or at the instigation of local and/or central authorities. For more factual information, see Van Houtte, Histoire économique, pp. 67-69.

57. For a more comprehensive analysis of the "inclusiveness" of the Antwerp guilds, see De Munck, Technologies of Learning, ch. 2.3, and idem, "Construction and Reproduction: The Training and Skills of Antwerp Cabinetmakers in the I6th and I7th Centuries", in Bert De Munck, Steven L. Kaplan and Hugo Soly (eds), Learning on the Shop Floor: Historical Perspectives on Apprenticeship (London [etc.], 2007), pp. 8 5- I IO. On this subject I disagree with Peter Stabel, who claims that guilds in late medieval Flanders were relatively open institutions, but that they tended to restrict access when they became increasingly focused on luxury industries and urban and regional supply from the sixteenth century onward; Stabel, "Guilds in Late Medieval Flanders", pp. 194-196.

58. Perhaps successfully as their total number of apprentices did approach the limit. With an apprenticeship duration of two years, a maximum of one apprentice per master (with the stipulation that the second could be hired after one year and nine months; CAA, GT 4334, fos $56 \mathrm{v}-58 \mathrm{v}$; GT 4335, 20 November I606, 73v ff) and an average of I 6 masters paying annual dues, cabinetmakers could hire 460 apprentices between $169 \mathrm{I}$ and $\mathrm{i} 760$. The total number actually hired was $4 \mathrm{I} 2$.

59. CAA, GT 4334, fos I-5v; GT 4335, I4 June I497 (copy). 
As a rule, when the entrance fees were raised in the following two centuries, registration fees rose more (in relative terms) than admission fees did, and the same principle (of being deductible from the entrance fee later on) applied. ${ }^{60}$ In the first half of the eighteenth century, after a complaint that their apprentices left the workshops of cabinetmakers to work for carpenters and thus "abandoned the registration fee", the registration fee for cabinetmakers was raised to 2I guilders, but upon becoming a master, I 8 guilders of the admission fee might be waived. ${ }^{6}$ Other craft guilds compensated for rising fees by simultaneously discontinuing the compulsory provision of "treats", such as paying for common meals or by accepting a cheaper master piece for qualification as a master. In the eighteenth century, the traditional requirement that new masters provide meals for guild members was for instance discontinued among the Antwerp carpenters and cabinetmakers, tinsmiths, plumbers, and tanners. ${ }^{62}$

It is not always clear whether guilds intended to be inclusive toward new masters or new journeymen. My hypothesis would be that it depended on the labour relations in the trade and the power structure within the guilds, but more research is needed here. In some guilds, in any case, the increased prevalence of sons of current masters on the lists of new masters was the result not of "corporatist strategies" but of structural problems relating to the reproduction of "mastership" itself. ${ }^{6}$ In the Guild of Tanners in Antwerp, for example, the increased proportion of masters' sons qualifying as masters seems to have been a function of the total decline in the number of new apprentices after the 1750s. As the very last apprentice was registered in November 1759, some thirty-five years before the abolition of the guild, there must have been a shortage of prospective masters. The Tanners' Guild in Mechelen on the other hand, drastically reduced the registration fees for apprentices who agreed to work as journeymen only (and not as masters) in 1775 . Two years later the ban on hiring unfree journeymen was lifted. ${ }^{64}$ These measures arose from the need for a sufficient number of skilled journeymen per master. In both cases, craft guilds exuded insufficient appeal, as reflected in a shortage of new apprentices who would later become either free journeymen or masters.

60. CAA, GT 4334, fos 7v-9v; GT 4335, 6 August I I I ; GT 4334, fos 31-33; GT 4335, 3 I March I 543 ( I 544) (copy); GT 4334, fos 50-5 I; GT 4335, 26 July I 595 (copy); GT 4334, fos 6466v; GT 4335, 28 April I62 I (copy); GT 4004, fos 6r-7r, 29 April I647; GT 4334, fos 8 Iv-82v; GT 4335 (copy).

6r. CAA, GT 4335, 22 and 3 I January, and 7 February 1735, 9 December i743, fo. I34v ff. Cf. De Munck, "Construction and Reproduction", pp. 92-95.

62. CAA, GT 4264, 2 November I7I 2; PK 793, fo. 259; GT 4I I 2, I7 February 1746, fo. I63r, art. 5; CAA, GT 434I, 9 March 1746, arts 4 and 9; GT 4264, 22 October I 770.

63. Masters' sons gradually paid higher entrance fees as well, also in relative terms (compared to those who were not masters' sons). See De Munck, Technologies of Learning, ch. 2.3.

64. B. Ballaux, "De Mechelse huidenvetterij in het Ancien Régime: van exportindustrie tot nijverheid van regionaal belang”, Bijdragen tot de Geschiedenis, 82 (1999), pp. $25-26$. 
From this perspective, the abolition of corporative regulations should be re-examined. There are reasons to believe that the ordinance of 9 February 1784, which effectively abolished all restrictions on the number of journeymen a master could employ, had little impact in reality. ${ }^{65}$ The increase in the number of dispensations granted on apprenticeship terms (especially from the beginning of the eighteenth century onwards ${ }^{66}$ ) was perhaps attributable more to the practical limitations on the supply of apprentices overall than as a systematic attempt to undermine the institution per se. The problem was not that the workshops of some masters gradually grew larger and larger but the lack of skilled, or rather "qualified", labour. After all, in 1738 in Antwerp, only 722 official apprentices were registered (barely I.3 per cent of the population of $55,000) .{ }^{67}$ Comparing this share with sixteenth-century London, where about Io per cent of the population consisted of apprentices, ${ }^{68}$ reveals that the situation on the labour market was totally different in Antwerp (at least after I 585 ). The question then is why Antwerp craft guilds lost their appeal.

\section{DISTINGUISHING APPRENTICESHIPS}

All this does not necessarily mean that the role of the apprenticeship system diminished. In recent research, apprenticeship is seen to have stimulated masters to invest in training and to have enhanced product quality. ${ }^{69}$ In Antwerp, the application of such a hypothesis remains

65. Van Houtte, Histoire économique, p. 97.

66. Ibid., p. 84; D. Schlugleit, De Antwerpse goud-en zilversmeden in het corporatief stelsel (1382-1789) (Wetteren, I969), pp. 210-220; S. Stacino, "Het Brusselse goud- en zilversmedenambacht onder Oostenrijks bewind (I $8 \mathrm{de}$ eeuw)" (unpublished licentiate thesis, Vrije Universiteit Brussel, 1998), pp. 24-25. Cf. J.R. Kellett, "The Breakdown of Guild and Corporation Control over the Handicraft and Retail Trade in London", Economic History Review, I0 (1958), pp. 38I-394.

67. CAA, GT 4006, Guild survey of 1738 , published and annotated by Frans Smekens, De verzamelde geschriften van Frans Smekens (Borgerhout, s.d.), pp. 62-67, (Bijlage II. Ambachten. Toestand in 1738 ). For Ghent the figure was $2, \mathrm{II}_{3}$ apprentices, or 4.8 per cent of the total population (50,000); General State Archives Brussels, Council of Finance, 4320, II, and City Archives Ghent, Series I 56, Nr 3. For Brussels it was 542 apprentices for a population of 66,500, or 0.8 per cent; Karin Van Honacker, "De politieke cultuur van de Brusselse ambachten in de achttiende eeuw: conservatisme, corporatisme of opportunisme?", in Catharina Lis and Hugo Soly (eds), Werken volgens de regels. Ambachten in Brabant en Vlaanderen, I500-I 800 (Brussels, 1994), pp. 223-225.

68. See Steve Rappaport, "Reconsidering Apprenticeship in Sixteenth-Century London", in John Monfasani, Ronald G. Musto, and Eugene F. Rice (eds), Renaissance Society and Culture: Essays in Honor of Eugene F. Rice Jr (Ithaca, NY [etc.], I99I), pp. 240-24I, 239-26I. See also Steve Rappaport, Worlds within Worlds: Structures of Life in Sixteenth-Century London (Cambridge, 1989), pp. 232-234, 29Iff; and Ian W. Archer, The Pursuit of Stability: Social Relations in Elizabethan London (Cambridge, 199I), esp. chs 4 and 6.

69. Epstein, "Craft Guilds"; Gustafsson, "The Rise and Economic Behaviour". 
inconclusive, but it does seem that, in the long run, economic elites at least lost interest in utilizing the apprenticeship system for these reasons. By the middle of the eighteenth century, most master carpenters actually tried to dismantle the terms of the apprenticeship system. They attracted "unfree" journeymen (those who had not completed a formal period of apprenticeship), who were not only known to work for lower wages but, moreover, were also perceived as being better trained than many of their qualified counterparts. ${ }^{70}$ The situation was similar in the textile sector, where specialists were often attracted from abroad to train local journeymen in cotton printing. ${ }^{7 \mathrm{I}}$ In the Guild of Cloth Dressers, immigrant artisans were actually paid more than local journeymen in I606, suggesting that apprenticeship was an obsolete mechanism for training in a craft. ${ }^{72}$

Since masters preferred that their workers were familiar with a broad range of state-of-the-art techniques, the diverse experiences of unqualified journeymen, "shopping" from master to master and town to town, seems to have been preferable and more convenient. ${ }^{73}$ Sometimes the rules governing apprenticeship were supported, not by masters but by journeymen. For qualified journeymen, apprenticeship provided an opportunity to exclude unlicensed workers and thereby to defend their own wages and employment opportunities. This depended, however, on the so-called "right of preference", which prevented masters from hiring workers who did not complete an apprenticeship term and guaranteed a minimum wage for those who did. ${ }^{74}$ This rule existed only in very specific guilds, however, typically those with large numbers of journeymen. ${ }^{75}$ Only in these guilds did apprenticeship relate to labour market entrance. In other guilds, the apprenticeship system was important only for masters. In the absence of a right of preference (i.e. in all guilds examined in this article except that of

70. CAA, GT 4345, Contrarie Redenen, fo. 67ff, I762; GT 4345, fo. I02ff, Advies 22 October, I770. See also De Munck, "Meritocraten aan het werk".

7r. Thijs, Van "werkwinkel" tot "fabriek", p. 369. In the silk industry, masters did not find enough journeymen because of the very low wages they were prepared to pay them (pp. 374375, 397).

72. CAA, GT 400 I, fo. 53 , copy in GT 4030 , fos $53-53 \mathrm{v}$.

73. CAA, GT 4345, fo. I02ff, 22 October I770; GT 4345, Memorie, fo. I $23 \mathrm{v}$.

74. In the construction industry, for example, journeymen often claimed a right of preference at a certain minimum wage. Johan Dambruyne, "De Gentse bouwvakambachten in sociaaleconomisch perspectief (I 540-I795)", in Lis and Soly, Werken volgens de regels, pp. 5I-105, 87; De Munck, "Meritocraten aan het werk". See also Deceulaer, Pluriforme patronen, p. 294 for the hosiery makers; and Catharina Lis and Hugo Soly, "De macht van 'vrije arbeiders': collectieve acties van hoedenmakersgezellen in de Zuidelijke Nederlanden (zestiende-negentiende eeuw)", in idem, Werken volgens de regels, pp. I 5-50, for the hat makers.

75. Apparently, it didn't exist in craft guilds as diverse as the gold and silversmiths, the diamond cutters, the shoemakers, the cabinetmakers, the pewterers, and plumbers and so on. See for example: 24 February I454, art. 2 (gold and silversmiths); Ordinance 25 October I 582 , art. 25 (diamond cutters); CAA, GT 4II2, 30 January I606, fos 94v-95; GT 4II2, fos 86v-87v, 24 November I603 (shoemakers). 
the carpenters), the apprenticeship system did not define who could become a journeymen but who could become a master.

In general, the problem was not that there were too many apprentices on the shopfloor, but rather that registered apprentices were absent from their primary workplace, and were working at other locations, either on their own account or directly for non-guild-based entrepreneurs. ${ }^{76}$ Whether the output of masters was sold in its entirety to a single merchant was not an issue, nor was the practice of several journeymen, or even fauxcompagnons, working at the same workshop. The point was that products had to be made under the supervision of a regular master and that only masters could employ apprentices and journeymen. ${ }^{77}$ Above all, it had to be clear who could call himself "master". Several very important regulations, introduced ostensibly for other reasons, were issued to distinguish masters from faux-maîtres. Masters were forbidden, for example, to found companies, as this would enable them to regulate unfree or illegal entrepreneurs..$^{78}$ In order to prevent the realization of such scenarios, masters were even obliged to reside in the premises they worked in, and furthermore, were also denied the opportunity to open shops outside their own houses. ${ }^{79}$ For the same reason, free and unfree journeymen were sometimes allowed to work for a master only when they lived or at least worked directly on his premises. ${ }^{80}$

The role of the "master piece" can be better understood from this perspective too. In theory, the systematic testing of skills and proficiencies at the end of the term of craft employment did allow the skill of the

76. See for example CAA, GT 4264, I March I 543 (I 544); GT 4002, 22 November I 574 , fo. 65 r; GT 4485 , nr. 3, fo. I4v; GT 4II6, I June I669.

77. Some examples: CAA, GT 4485, nr I 5 , I 3 and 27 September I688, fos 33 r-33v. See also Deceulaer, Pluriforme patronen, p. $30 \mathrm{I}$, who found that the Guild of the Tailors objected far more vehemently to unfree artisans who acted as masters themselves than to unfree journeymen working (from their own premises) for a regular master. For additional arguments and empirical evidence for this hypothesis, see Bert De Munck, "La qualité du corporatisme. Stratégies économiques et symboliques des corporations anversoises du XV siècle à leur abolition", Revue d'histoire moderne et contemporaine, 54 (2007), pp. I I6-I 44 .

78. See for example 25 October I 582, arts 30-34 (diamond cutters); Schlugleit, De Antwerpse goud- en zilversmeden, pp. I39ff, 242-248; CAA, Process dossiers (hereafter P), A 562, I65 II652; GT 4485, no. 2, 9 February I 557, fos I3-I3v (gold and silversmiths); GT 4264, I March I 543 (I 544) (pewterers and plumbers).

79. CAA, GT 4028, 20 September I696, art. Io (cloth dressers); GT 4485, nrs I 5, I3, and 27 September I688, fos $33 \mathrm{r}-33 \mathrm{v}$ (gold and silversmiths).

80. CAA, GT 4002, 22 November I 574 , fo. $65 \mathrm{r}$ (gold and silversmiths). See also GT 4485, nr. 3 , fo. I4v; GT 24 November I603, fos 86v-87v; GT 4II2, 30 January 1606, fos 94v-95r (shoemakers). In other occasions this seems to have been allowed. In I 497 a master cabinetmaker could explicitly employ his journeymen "inside or outside his house"; CAA, GT 4334, fo. Iff; GT 4335, I 4 June I 497, fo. 2v. The same was ruled for the ebony workers in I62 I: CAA, GT 4334, fos 65r-66v; GT 4335, 28 April I62 I, 83v ff, art. 9. And large master entrepreneurs among the hosiery makers commissioned work to non-guild based artisans who worked from their own premises; Deceulaer, Pluriforme patronen, pp. I44-I45. 
practitioner to be audited and indeed regulated, but in practice it seems to have been more instrumental in serving another aim. In the southern Netherlands, the requirement for the production and certification of master pieces was established somewhat belatedly between the late fifteenth and early seventeenth centuries. ${ }^{81}$ Even after they had been established, moreover, guild officials could often, according to the specialized training the prospective master had acquired, prescribe a specific ad hoc test. This was the case, for instance, with the Guild of Diamond Cutters in I 582 , the Guild of Gold and Silversmiths in I 524, and the Guild of Cabinetmakers in $1543 .{ }^{82}$ This suggests that the testing criteria were not intended to exclude workers who could not reach very strict quality standards.

Besides, the requirement to produce a master piece was not in itself designed to test the skills of journeymen, but was intended to test the skills of the masters only - except, significantly, when free journeymen were distinguished from unfree ones. ${ }^{83}$ This meant, of course, that apprenticeships did not produce technical knowledge, but in fact addressed the authority to supervise and organize the work process. Adding to this the fact that prospective masters enjoyed promotion almost without exception, reveals that the creation of a labour-market monopsony - perhaps linked to a certain familiarity with product standards - was indeed more important than the transfer of skills.

In my view, the master piece requirement served to exclude groups who wanted access to skilled labour without having first acquired such skills themselves - namely large merchants. ${ }^{84}$ The central problem was that large merchants or illegal entrepreneurs tried to become masters without having learned the trade. They might register as apprentices in the guild's books, or they could use the trademarks and/or the names of regular masters to legalize their work. ${ }^{85}$ This explains why the cabinetmakers in 15 is reacted

8I. A trial piece was first mentioned in 1497 for the Antwerp cabinetmakers, in I 523 for the tinsmiths, in I 524 for the gold and silversmiths, in I 543 (probably) for the carpenters, and in I 583 for the shoemakers and tanners.

82. 25 October i 582, p. I6, art. 20; CAA, GT 4488, 24 November i 524 , art. 9, fos i I 5 v-i i 6; GT 4335 , 3 I March 1543 .

83. The Antwerp carpenters in the sixteenth century, for example, prescribed two different trial pieces, one for new journeymen and one for new masters; CAA, GT 434I, 3I March I 543, arts 5-6. The same applies for the cloth dressers and masons. Cf. Etienne Scholliers, "Vrije en onvrije arbeiders, voornamelijk te Antwerpen in de I6de eeuw", Bijdragen voor de Geschiedenis der Nederlanden, i I (1956), pp 285-322, 288, 291-292.

84. One example is the famous Guillaume Forchondt, who succeeded in becoming a master ebony worker without being able to handle a plane, as some ebony workers (who were working for him) stated in a lawsuit filed against him by the guild; CAA, Proceedings A 868, 3 I September 1648; Insolvente Boedelkamer 728/2, P 1637. See also Ria Fabri, De I7de-eemwse Antwerpse kunstkast. Typologische en historische aspecten (Brussels, I99I), p. I I 5.

85. CAA, GT 400I, 2 August I 493, fos I 28 - I 29 (carpenters); GT 4488, fo. 82; GT 4485, no. I, 24 January I 543, fos I Ir-I 2v; GT 400I, fos I 87v-I88; GT 4002, 22 November I 574, fo. 64v; GT 
to a complaint about apprenticeship being neglected by requiring a more difficult master piece instead of formulating additional rules about apprenticeship itself. ${ }^{86}$ The master piece served to prevent merchants or other faux-maitres employing unfree journeymen or other workers legally themselves, instead of subcontracting work to masters. Without strict adherence to apprenticeship regulations, they could even employ masters directly, reducing them to mere piece workers.

When the requirement for masters to produce a trial piece still failed to prevent merchants or faux-maîtres from gaining access to qualified workers, something more coercive was introduced. Guild boards thereafter required apprentices to live directly on their masters' premises. Wherever this obligation appeared in guild ordinances it reflected an attempt to address problems of illegal work and to define the status of the apprentices at issue. ${ }^{87}$ It served to prevent the fictitious apprenticeships of merchants or faux-maitres, who tried to circumvent master status by becoming masters themselves without actually serving as an apprentice. ${ }^{88}$ Another measure that served to prevent this was a maximum age for apprentices, which was, for example, discussed by the gold and silversmiths in the eighteenth century. ${ }^{89}$ Rather than emanating from paternalistic concerns, the obligation for apprentices to board and the prohibition for adults to register as an apprentice served to defend master status and to distinguish legal from illegal workers.

In sum, craft guilds defined carefully and precisely who was entitled to manufacture products, to have access to skilled labour, and to use the collective trademarks. The central issue is the link between the (legitimization of the) masters' labour-market monopsony on the one hand and the (construction of) product quality on the other. Guild-based trademarks signalled that a product was manufactured by or under the close supervision of an artisan operating legally inside a specific city, i.e. by a guild member who had completed his official training.

4485 , no. 3, fo. I 4v; GT 4488, fos 76-78, 82 (gold and silversmiths); GT 4337, I 9 July i 694 , fo. 36 (cabinetmakers); GT 4028, 20 September 1696, p. I 23, arts 7, 8, and Io (cloth dressers). See also Deceulaer, Pluriforme patronen, p. I62.

86. CAA, GT 4334, fos 7v-9v; GT 4335, 6 August is is (copy). Compare this with the shoemakers and tanners, where a master piece was required because "some persons were admitted to the guild that afterwards appeared to be unable to make proper and honourable pieces"; CAA, GT 4I I2, i 8 April i 583 , fos 62r-62v.

87. CAA, GT 4264, I March I 543 (I 544); GT 4004, 4 July I65 I, fos 42v-43v (pewterers and plumbers); GT 4488, 24 January I 543, fos 76r and 78r (gold and silversmiths); GT 4028, 20 September 1696, art. I (cloth dressers).

88. The notaries' archives contain contracts in which a merchant agrees to "learn" with a master cloth dresser in return for exclusiveness in the finishing of all his cloth for the master (on top of a "learning fee" of several hundred guilders); CAA, Notary Archives (hereafter N) 2913, 9 February 1752.

89. Schlugleit, De Antwerpse goud-en zilversmeden, pp. 242-248. 
In what measure the guilds actually succeeded in providing better products is, however, open to question. Since a supply of skilled labour for many products could also be acquired on a free market outside the guilds, from "footloose" labourers and migrants, the purported higher quality of guild-based products was not necessarily apparent at all times. This would in any case be impossible to determine, as product quality cannot be measured objectively. From an economic perspective, objectification of "quality" takes place through mathematical equation of supply and demand via the "price-mechanism", but cultural standards and beliefs of course "precede" the price mechanism. ${ }^{90}$ That is why marketing, the use of quality labels and the like, can influence prices. Applied to the craft guilds, it becomes clear that the apprenticeship system was focused on certifying (i.e. objectifying) the quality of the skills to be applied rather than on guaranteeing product quality as such.

The formal apprenticeship system not only created a labour-market monopsony and a concomitant distinction between masters and fauxmaîtres but also led to a distinction between "qualified" and "unqualified" products. Without necessarily being able to make a verifiable difference between the qualitative variations of final products, craft guilds tried to define the standards by which "quality" could and should be measured. Ultimately, it was the master's "quality" that guaranteed product quality, but, as with product quality, this cannot be measured objectively.

\section{QUALITY STANDARDS AT WORK}

Conventions objectifying the quality of labour and products can best be defined, whether from the viewpoint of employees or customers, as "mutual expectations concerning the competency and behaviour of others" ${ }^{91}$ Such conventions themselves are based on general perceptions about fairness and the common good, ${ }^{22}$ which means that craft guilds defined product quality and human competency in relation to the cultural standards of the time. With regard to the social construction of quality,

90. See, in particular, François Eymard-Duvernay, "Conventions de qualité et formes de coordination", Revue Économique, 40 (1989), pp. 329-359, and, idem, "Coordination des échanges par l'entreprise et qualité des biens”, in André Orléan (ed.), Analyse économique des conventions (Paris, 1994), pp. 33 I-358; Pierre-Yves Gomez, Qualité et économie des conventions (Paris, 1994); and the dossier on "La qualité", in Sociologie du Travail, 44 (2002). See also the pioneering work of George A. Akerlof, "The Market for Lemons: Qualitative Uncertainty and the Market Mechanism", Quarterly Journal of Economics, 84 (1970), pp. 488-500; and Joseph Stiglitz, "The Causes and Consequences of the Dependence of Quality on Price", Journal of Economic Literature, 25 (1987), pp. I-48.

9I. "[...] un système d'attentes réciproques concernant les compétences et les comportements des autres"; Robert Salais and Michael Storper, Les mondes de production (Paris, I993), p. 3 I. 92. Cf. Luc Boltanski and Laurent Thévenot, De la justification. Les économies de la grandeur (Paris, 1991). 
then, it is important to first identify the specific qualities and competencies that were defined and certified by the guilds.

Product quality was highly variable. In the (late) sixteenth century, the emphasis had shifted from a market where standardized mass production was the norm to one where luxury products, exhibiting a higher added value, were much more in demand. Especially during the period of the Counter Reformation, product forms became more complex, resulting in uncertainty about product quality. As artistic influence took precedence over strictly mechanical skills, established forms of product certification and existing patterns of consumer loyalty came under increasing pressure. In this context, guild-based masters had to develop new criteria to measure product quality and, at the same time, to legitimize their own unique claim to the authentication of such standards. Why should a master shoemaker within Antwerp, for example, be paid more for a pair of shoes than a craft shoemaker operating outside the city walls? Why indeed should a master silk weaver, working for a merchant, earn more per piece for operating within his own dwelling than working for a large master (as a piece worker) on the latter's premises?

The response of the guild boards to such issues was of course inevitably vested in the often arbitrary concept of "craftsmanship". Yet the guilds' strategies to "guarantee" product quality do not mirror the socalled skill-enhancing function of apprenticeship. In practice, rather than check whether a product exhibited a high level of craft skill as such, inspections were undertaken by deacons or elders in order to warrant whether the materials used were of the proper quality. In the Shoemaker's Guild, for example, the leather used was checked to see if it had been properly tanned. In other guilds, the deacons or elders considered whether the silver employed was of a suitably high carat, whether the tin did not contain too much lead, and whether the proper wood had been used. ${ }^{93}$

Trademarks were supposed to make distinctions between the different grades of raw materials employed. Silver and tin ware bore different marks according to the composition of the alloy, ${ }^{94}$ furniture according to the wood used, ${ }^{95}$ and leather according to the piece of skin being tanned. ${ }^{96}$ Hides tanned outside the city walls of Antwerp, and thereafter imported for subsequent processing therein, carried a differentiated trademark to distinguish their source location and thus differentiate them from leathers

\footnotetext{
93. Cf. De Munck, Technologies of Learning, chs 2.2 and 6.

94. Schlugleit, De Antwerpse goud-en zilversmeden, pp. 20-2 I, 42-45, 78, I 34; P. Baudouin, P. Colman, and D. Goethals, Edelsmeedkunst in België. Profaan zilver XVIde-XVIIde-XVIIIde eeuw (Tielt, I988), p. I3; Van Deun, "Het Antwerpse tinnegietersambacht", pp. 35-62; Edmond Geudens, Het hoofdambacht der meerseniers, II: Burgerdengd (Antwerp, I904), pp. I I0-I I 2. 95. CAA, GT 4334, fo. 66; GT 4335, 28 April I62 I, (copy).

96. CAA, GT 4I I 2, 3 May i 593; GT 4I I 2bis, fos 86-88, Alsoo [...], (copy).
} 
tanned inside the city. ${ }^{97}$ High quality English tinware would bear the mark of the "Tudor Rose", whereas the equivalent tinware from Antwerp, albeit only slightly inferior in grade, had to be marked with an Antwerp rose instead. In fact, each time another grade of alloy was allowed, another mark would have to be created in order to distinguish it from the "qualities" of other rival products..$^{9}$

Even within the same guild, every "quality level" had its own authentication mark. The Guilds of Shoemakers and Tanners, Gold and Silversmiths, and Pewterers and Plumbers had several marks, each referring to a different grade of raw material employed. So just as the existence of apprenticeship did not, as such, validate the claim to the possession of superior levels of skill, warranting goods by the use of trademarks did not in itself guarantee a superior product - trademarks first of all served to distinguish one product quality from the other. In Antwerp both a "hand" and a "fortress" were typically used as a seal of approval, for example by the shoemakers and the pewterers and plumbers, respectively. 99 Consequently, trademarks should not be assumed to be the result of more product standardization. The use of trademarks rather signals the increasing de facto absence of quality standardization. These marks were supposed to "objectify" or "fix" product quality by distinguishing one product from another. ${ }^{100}$ In doing so, trademarks guaranteed the honesty of the craftsmen that used them, not their technical abilities.

At the same time, guild-based masters tried to cultivate a better image for their manual skills on a representational level. Displayed proudly during processions, the livery of their "blazons" often depicted their tools or products - as a reference to the primacy of their skills. ${ }^{\text {IOI }}$ In order to understand this adequately, we should consider the cultural context these artisans worked in. There are signs of a growing dichotomy between conception and execution, which could help to explain, in the absence of other decisive changes within the labour market, why the guilds perpetuated the image of "craftsmanship". ${ }^{\text {102 }}$

97. CAA, GT 4 I I 2, fos 25v-26; GT 4 I I bis, fo. 27, I6 September I 5 I7 (copy); another copy in GT 4 II 6.

98. Van Deun, "Het Antwerpse tinnegietersambacht", pp. 35-62.

99. CAA, GT 4I I2, 3 May i 593, fos 74-75; 4 I r 2bis, fos 86-88; Van Deun, "Het Antwerpse tinnegietersambacht", pp. 4 off.

ı००. For additional information, see De Munck, Technologies of Learning, ch. 6.3; and "La qualité du corporatisme".

Iо I. P. Génard, Wapenboek der Antwerpsche gemeente-instellingen, sedert de vroegste tijden tot op onze dagen (Antwerp, I883). See Bert De Munck, "Erfgoed is van alle tijden. Ambachten en hun beeldcultuur in het Ancien Régime", in André Vandewalle (ed.), Te Wapen! Heraldiek, teken van gezag en identiteit (Bruges, 2004), pp. 29-45.

I02. According to Hélène Vérin, "La réduction en art et la science pratique au XVIe siècle", in Elisabeth Chatel, Robert Salais, Dorothée Rivaud-Danset (eds), Institutions et conventions. La réflexivité de l'action économique (Paris, I998), pp. I19-145, the relation between theory and 


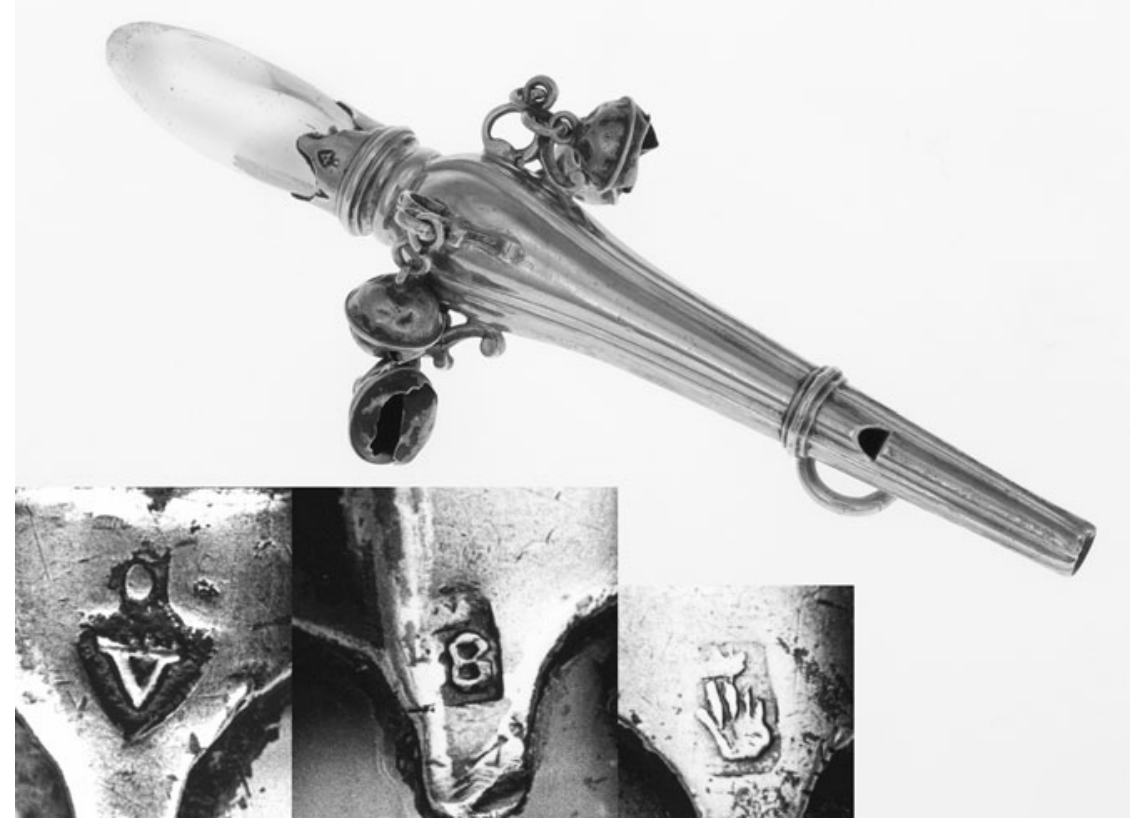

Figure I. Silver rattle with a whistle and four bells; Joannes Balthasar II van Oppervelt, Antwerp, I788, inv. nr. S63/I I.

Photo: Hugo Maertens

Marks on the rattle: a master's mark (V and a dot), a date mark $(88=\mathrm{I} 788)$, and the hallmark of Antwerp (the crowned hand).

Photo: Jacques Sonck. Copyright Silvermuseum Sterckshof, Province of Antwerp. Used with permission.

It is well known that the liberal arts were traditionally valued much more highly than manual skills were, but around i600 another distinction seems to have come to the fore. Some craftsmen, especially painters and sculptors, began to pursue the prestige of "men of letters". From the sixteenth century onwards, Antwerp painters started to depict themselves even within their own self-portraits without tools. The Guild of Stonemasons, furthermore, no longer wished to be associated with bricklayers within the confines of a single guild. They too wished to distance themselves from the image of simplistic and primitive manual work. ${ }^{103}$

practice changed drastically as a result of attempts to mechanize intellectual capacities and to reduce practical knowledge. This tendency did not result in a natural science applied to certain techniques, but in a practical science (science pratique) concerning the conception and production of artefacts.

103. Zirka Zaremba Filipczak, Picturing Art in Antwerp, I550-1700 (Princeton, NJ, 1987), pp. II-I9; A. Lipsmeier, "Technik, Kunst und Berufsbildung. Aphorismen zu einem alten 
Gradually, therefore, not only liberal arts but also artistic and designing skills seem to have prevailed over operational skills.

The first guild to be abolished on 20 March 1773 was the Guild of Saint Luke. ${ }^{104}$ At that time, the trade had already faced competition from the Antwerp "Académie Royale des Arts de la Peinture et Sculpture" for over a century. The art academy, the first of its kind in the southern Netherlands, was established in I663 and was modelled after the example of the "Académie des Beaux-Arts de Paris", which is associated with the rise of the classicist style. ${ }^{\text {I05 }}$ The official idea was to give the art sector a boost, ${ }^{106}$ but the academy was founded in an age of transformations in the field of tension between conception and execution. For classicist and even baroque artists, design had indeed become more important than in the past. ${ }^{107}$ At the same time, there seems to have been an increasing difference between high-level and lowlevel artists. While the former continued to be responsible for conception and execution - their "manner" or "style" became even more important - the latter were doomed to copy or to paint standardized pieces inspired by the work of others. ${ }^{\text {IO } 8}$ Most artisans suffered from an increasing tension between art and handicraft. While the Guild of St Luke did not distinguish between arts and handicrafts as carvers, gilders, and bookbinders were not distinguished from painters and sculptors - designing skills were clearly distinguished from operational skills when the art academy was founded.

The conflict between operational skills on the one hand and designing or intellectual skills on the other is best illustrated according to the respective value of academic knowledge and practical skills in the medical sector. With the establishment of the Antwerp Medical College at the beginning

berüfspädagogischen Thema in aktueller Sicht", Jahresbericht des Instituts für Berüfpädagogik der Universität Karlsrube, I985/86, pp. I3-24, I6. See also C. Duvivier, "Contestation entre la confrérie des maçons et les sculpteurs d'Anvers (г606)", Revne d'Histoire et Archéologie, 3 (I86I), pp. 9I-94.

104. L. Galesloot, Documents relatifs à la formation et la publication de l'ordonnance de MarieThérèse du 20 mars-I3 novembre 1773 qui affranchit les peintres, les sculpteurs et les architectes, aux Pays-Bas, de l'obligation des se faire inscrire dans les corps de métiers (Antwerp, i867).

105. Cf. Nicolas Pevsner, Academies of Art: Past and Present (New York, 1973). For the southern Netherlands: G.A. De Wilde, Geschiedenis onzer Academiën van Beeldende Kunsten (Leuven, I94I).

I06. CAA, Collegiael Actenboek, r663, fo. 5; and De Munck, "Le produit du talent".

107. For the increasing importance of design tools and procedures in early Netherlandish painting, see Arnout Balis, "Working it Out: Design Tools and Procedures in Sixteenth- and Seventeenth-Century Flemish Art", in Hans Vlieghe, Arnout Balis, and Carl Van de Velde (eds), Concept, Design and Execution in Flemish Painting (Turnhout, 2000), pp. I29-I I I.

I08. Elizabeth Honig, "The Beholder as Work of Art: A Study in the Location of Value in Seventeenth-Century Flemish Painting”, in Reindert Falkenburg, Jan de Jong, Herman Roodenburg, and Frits Scholten (eds), Image and Self-Image in Netherlandish Art, I550I750 (Zwolle, I995), pp. 253-293. 
of the seventeenth century, ${ }^{109}$ academic physicians increasingly dominated the guild-based surgeons and pharmacists. By presenting their profession as being superior to that of more basic guild practitioners, they tried to expand their control over the prescription of treatment and medicines. Guild-based craftsmen, by this view, should only produce medicines and implement cures that had been diagnosed and prescribed by their professional superiors. ${ }^{10}$

The craft guilds reacted to this potential loss of professional autonomy by seeking to emphasize the continuing importance of their practical skills. This became a central bone of contention in discussions concerning the form of examinations that prospective surgeons should pass for graduation at the Collegium Medicum. ${ }^{\text {II }}$ The Deacons of the Guild of Surgeons stressed the importance of manual dexterity and the more applied aspects of their craft, competencies that should also be apparent even within the confines of the oral examination. They considered that theoretical training at college was largely unnecessary because, in their view, only practical experience could provide the necessary competencies. ${ }^{\text {II }}$ Similar arguments surfaced with the gold and silversmiths, who claimed that "it is sure that the years of apprenticeship are equal to [the time spent at] schools for the sciences". ${ }^{\text {II3 }}$

Not coincidentally, the only guild that really thrived in the seventeenth and eighteenth centuries was the Mercers' Guild, known as an organization of faiseurs de rien, vendeurs de tout. It is important to note that Antwerp at that time evolved from a "fashion maker" into a "fashion taker", causing major difficulties for the "traditional" luxury sectors. The import of especially French products went hand in hand with the economic success of a group of retailers, selling products made and conceived elsewhere. ${ }^{\mathrm{II}} 4$ Increasingly, then, craft guilds centred on purely

109. 28 April 1620 was the official date. Cf. C. Broeckx, Histoire du Collegium Medicum Antverpiense (Antwerp, 1858 ), passim.

I I0. CAA, GT 45 I5, fo. 2, 6 June 1659 (printed version in GT 45I3); Wetten ende regulen van het Collegie der medicynen by een vergaert door last vande Heeren Borgemeesters en wet alhier, I 2 April I659; published in Broeckx, Histoire du Collegium Medicum, pp. 8 I-82. See also CA, GT 45I3, 7 July I7I3; GT 45I3, Intendit, I5 November 1713; GT 45 I3, Ampliatie, art. 8.

I I I. CAA, GT 4077, fo. 19, I64I; GT 4077, fo. I25ff, Grieven, 20 May 1756; Requeste vande Apotekers aen myne heeren den Borgemeestere Schepene ende Raedt der stadt Antwerpen. See Broeckx, Histoire du Collegium Medicum, p. I44.

I I2. De Munck, "Medische praktijken".

I I 3. "T'is emmers zeker dat de leerjaren zyn gelyck aen de leerscholen voor de wetenschappen [...]"; CAA, GA 4490, s.d. quoted in Schlugleit, De Antwerpse goud-en zilversmeden, p. 320. I I 4. See the two doctoral theses on the Antwerp retail sector defended recently at the University of Antwerp: Ilja Van Damme, "Antwerpse klanten en kleinhandelaars tussen continuïteit en vernieuwing, ca. I648-1748" (unpublished doctoral thesis, University of Antwerp, 2006); and Laura Van Aert, "Leven of overleven? Winkelhouden in crisistijd: de Antwerpse meerseniers, ca. I648- ca. I748” (unpublished doctoral thesis, University of Antwerp, 2007). See also Bruno Blondé and Hilde Greefs, "Werk aan de winkel: de Antwerpse meerseniers: aspecten van 
manual craft came into conflict with guilds more focused on retailing and on developing conceptual skills and broader tertiary specializations. ${ }^{\text {II }}$

Significantly, the choice of a certain type of master piece within each of the guilds was itself highly arbitrary. As a rule, the prescribed task usually consisted of manufacturing a piece that was currently produced within the trade. While the submission of a final master piece was not required for journeymen and remained obligatory only for masters, individual competencies needed to run a business, such as book-keeping, were not tested. Moreover, several non-manual trades, such as the Guilds of Mercers and Second-Hand Dealers, did not require an examination at all.

In my opinion, therefore, a master piece - in addition to excluding illicit entrepreneurs - served to emphasize the continuing importance of the manual skills employed by guild members. The emphasis on the chef d'oewore demonstrates that guild-based artisans were not only seeking to counter their loss of autonomy over the production process, but also to counter the diminution of the importance of their manual skills. For guild members, the definition of high quality remained the province of the skilled craftsmen making the manufactures with their own hands. Inextricably bound up with this image was the fear of the influx of inferior products, either flooding in from the country or produced within the city itself. ${ }^{116}$

This brings us to the city context. Understanding how socio-economic and ideological factors are interwoven requires linking the material environment in which the actors operated with the "discourses" they mobilized. As was the case in Amsterdam, the discourse of the guild-based artisans created a distinction between urban-based artisans and unqualified outsiders. ${ }^{117}$ Masters regarded and pictured themselves as paternal "breadwinners", taking care of a wider family of workers and apprentices, and faithfully bearing the burdens and responsibilities of both their cities

kleinhandel en verbruik in de I7de en I8de eeuw", in De lokroep van het bedrijf: handelaars, ondernemers en bun samenleving van de zestiende tot de twintigste eeuw: liber amicorum Roland Baetens (Antwerp, 200I), (Bijdragen tot de geschiedenis, 84, I-3), pp. 207-229; Laura Van Aert and Ilja Van Damme, "Retail Dynamics of a City in Crisis: The Mercer Guild in PreIndustrial Antwerp (c.1648-c.1748)", in Bruno Blondé, Eugénie Briot, Natacha Coquery, and Laura Van Aert (eds), Retailers and Consumer Changes in Early Modern Europe: England, France, Italy and the Low Countries (Tours, 2005), pp. I43-I47; Blondé and Van Damme, "Een crisis als uitdaging?"

i I 5. De Munck, "Medische praktijken", and idem, "La qualité du corporatisme"; Van Damme, Antwerpse klanten en kleinhandelaars, pp. 438-448.

I16. This clearly appears in the well-known inquiry dating from 1738 , which was used, for example, by the gold and silversmiths to complain about unincorporated production in the country; CAA, GT 4006, fo. 33r, fo. 37 r, fo. 63 r.

I 17. Maarten Prak, "Individual, Corporation and Society: the Rhetoric of Dutch Guilds (I8th c.)", in Marc Boone and Maarten Prak (eds), Individual, Corporate, and Judicial Status in European Cities (Late Middle Ages and Early Modern Period), (Leuven [etc.], I996), pp. 255280. 
and their guilds. Not coincidentally, the guild and the city were explicitly linked in several coats of arms used by Antwerp guilds, such as the fishmongers and the butchers, which featured the image of the typical rhomboid-shaped fortress with the four towers. The Guild of Butchers had miniature hands upon the flags of the coats of arms, again an oblique reference to Antwerp (Figure 2). ${ }^{\text {II } 8}$ To legitimize their "privileged" status economically, craft guilds associated the common good of the city with high product quality. The keystone of the guilds' signage and "livery" consisted primarily of trademarks, which also explicitly referred to the specific town or city where the guilds were based - as was for example the case with the "crowned hand" of the gold and silversmiths. It was therefore no coincidence that most guild ordinances included the obligation for masters also to become burghers of the city in question.

\section{A CHANGING PERCEPTION OF GUILDS?}

Societies are invariably structured according to the perceived capacities of their members. Skills, competences, and thus "qualities", are inevitably linked to the cultural and symbolic aspects of the surrounding society. In the early modern urban context, the system of hallmarks embedded the product in a collective culture of reliable confrères, who were themselves seen as forming the backbone of an urban community based on craftsmanship. Therefore, the seal of approval was intrinsically a collectively recognized symbol. Personalized markings, often in the form of personal initials or abstract symbols, were secondary at best. In that respect, the traditional view of guilds as focused on the reproduction of a culturally legitimized ordre social, is understandable. "Corporatism" in a way corresponded with craft guilds creating a labour-market monopsony and a distinction between guild members and outsiders based on product quality.

As we have seen above, it was no coincidence that in the aforementioned statute of 9 February 1784 , only the labour market was "liberalized". Apart from resistance from some of the better organized journeymen, such as the hatters, the edict did not cause much trouble - most masters even seem to have welcomed it. ${ }^{119}$ The elimination of product monopolies, which the central government only ventured into rather reluctantly, ${ }^{120}$ however, was seen to be much more important than any formal deregulation of the labour market.

i 8. Génard, Wapenboek der Antwerpsche gemeente-instellingen. Cf. J. Gailliard, De ambachten en neringen van Brugge, of beschryving hunner opkoomst, bloei, werkzaembeden, gebruiken en voorregten (Bruges, I 854 ).

I I9. Cf. Yves Vanden Berghe, Jacobijnen en traditionalisten. De reacties van Bruggelingen in de revolutietijd (1780-1794) (Brussels, 1972), p. 67.

I 20. Van Houtte, Histoire économique, p. $96 \mathrm{ff}$. 


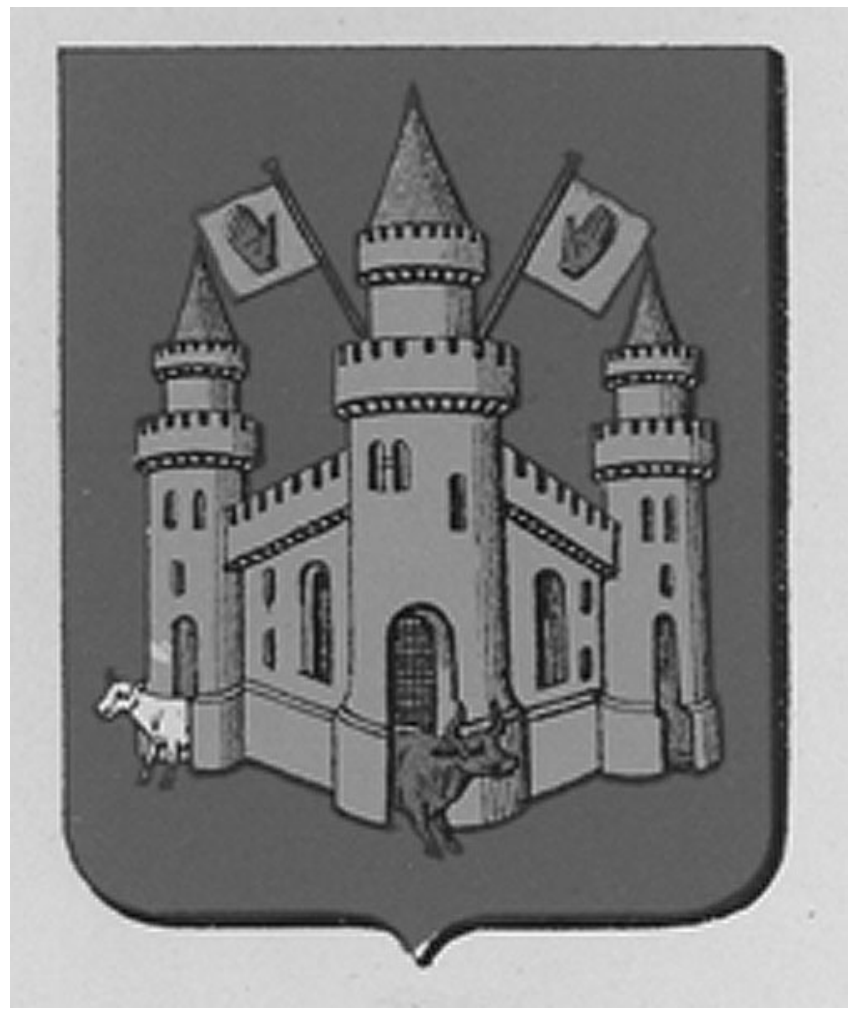

Figure 2. Coat of arms of the Antwerp butchers (from P. Génard, Armorial des institutions communales d'Anvers depuis les temps les plus reculés jusqu'à nos jours, Antwerp, I883, plate $\mathrm{XVII} / 9)$.

Copyright Municipal Library Antwerp. Used with permission.

In the end, however, the craft guilds' sophisticated strategies failed. Inspection of the probate inventories in Antwerp by Bruno Blondé and Carolien de Staelen has revealed the growing importance of smaller and cheaper silverware in the domestic interiors of Antwerp. This shift occurred at the expense of the traditional items that local gold and silversmiths were renowned for producing. By the first half of the eighteenth century, silver plates and beakers - typically bearing trade marks - were replaced by spoons, forks and salt tubs. ${ }^{121}$ As the guilds were oriented towards providing higher quality and more expensive products, this shift towards "populuxe goods" created major difficulties.

I2 I. Bruno Blondé and Carolien de Staelen, "Zilver in Antwerpen. Drie eeuwen particulier zilverbezit in context", (forthcoming). See also Blondé and Van Damme, "Een crisis als uitdaging?", pp. $66-76$ and $8 \mathrm{I}-83$. 
As early as the I970s scholars such as Joan Thirsk had defined the initial development of a "consumer society" in terms of a widening range of products and a greater diversity of forms of production. ${ }^{\mathrm{I} 22}$ More recently, it has been argued that both the continuing lack of standardization and the proliferation of different types of goods available had a profound impact on the type of information needed by merchants and indeed upon the "mysteries" of the trade. ${ }^{23}$ Changes in consumer preference thus called for specific strategies to regulate product quality on the supply side. One possibility would have been to broaden the definition of product quality and to classify the output in order to target diverse groups of buyers, thus "finding value in diversity", as the papermakers did in eighteenth-century France. ${ }^{24}$ In creating ever new quality marks, the Antwerp craft guilds obviously tried this as well, but in the long run they were not able to answer the new challenge.

In fact, the two most important strategies of the craft guilds were both undermined. First, the "quality" of the raw material mattered less to customers than before. In the eighteenth century, for example, the Antwerp diamond cutters were obliged to specialize in more general production, such as a more simple and standardized kind of jewellery (pieces formed in the shape of small roses). ${ }^{\mathrm{I2}}$ In the gold and silversmiths' trades, new lathes and presses emerged that were used to produce series of small items. ${ }^{26}$ Gradually, in the seventeenth and eighteenth centuries, the general output of the gold and silversmiths shifted towards relatively cheap items such as earrings, pendants, snuff boxes, small crosses, and all kinds of cast gadgets "which cannot be marked" ${ }^{127}$ Consequently, it is quite reasonable to imagine that retailers and customers alike were no longer influenced as much by the symbolic resonance of corporate trademarks.

Merchants, who had previously relied on the guilds to monitor product quality and police quality standards, had reason now to circumvent corporate regulations. Many merchants and suppliers even produced items which required different sorts of raw materials, such as ceramics and tin for making beakers, or leather and silver for belts. ${ }^{128}$ In these cases, guild

I22. Joan Thirsk, Economic Policy and Projects: The Development of a Consumer Society in Early Modern England (Oxford, 1978), ch. 5.

I23. Pierre Jeannin, "Distinction des compétences et niveaux de qualifications: les savoirs négociants dans l'Europe moderne", in Franco Angiolini and Daniel Roche (eds), Cultures et formations négociantes dans l'Europe moderne (Paris, I995), pp. 363-397.

I 24. Pierre Claude Reynard, "Manufacturing Quality in the Pre-Industrial Age: Finding Value in Diversity", Economic History Review, 53 (2000), pp. 493-516, 496.

I 25. Schlugleit, Geschiedenis van het Antwerpsche diamantslijpersambacht, pp. I48-i49.

I26. See for example: CAA, N Michiel Rongens, 6 October I649; De Gazette van Antwerpen (GVA) I742, no. 78; GVA, 28 July I746, no. 54; N 4524, no. 72, 20 June 1760.

I27. Quoted in Schlugleit, De Antwerpse gond-en zilversmeden, pp. 232-233; see also p. $270 \mathrm{ff}$. I28. CAA, GT 4265, Duplicque. D. Schlugleit, "De zilverhandel van de Meerse en de ordonnantiën van de goudsmeden te Antwerpen in de zestiende eeuw", Bijdragen tot de geschiedenis, 30 (1939), p. 5 I. 
regulations concerning mastership - which were mostly limited to one sort of raw material - were violated almost automatically. Even in the sixteenth century, several entrepreneurs had already begun to employ apprentices and journeymen directly. With regard to the status of the Guilds of Silver and Goldsmiths, there are even signs, from the end of the sixteenth century on, that they had lost credibility not only amongst consumers but even within their own ranks. ${ }^{129}$ Individual masters tended to circumvent the guild's prescriptions and produced "false" work. ${ }^{130}$

Secondly, the capacity to invent or design a new product was becoming more important than the capacity to make it. By the seventeenth and eighteenth centuries, prospective masters usually produced their own final master piece on the basis of externally sourced existing drawings or models. ${ }^{13 \mathrm{I}}$ Whilst in $\mathrm{I} 523$ trainee tinsmiths were still obliged to make an individual mould for their master piece themselves, by 1705 it was explicitly stated that the required copper moulds could be borrowed from the guild. ${ }^{132}$ This does not, however, mean that the ability to create individual designs became unimportant, rather the reverse. ${ }^{133}$ In Brussels, for instance, it remained important for master shoemakers to be able to make their own designs, not least because attractive designs were invariably associated with better wages. ${ }^{134}$ In I 632, moreover, shoemakers in Mechelen were not allowed to use existing models to complete their final master piece at all: they had to make their own designs instead. ${ }^{135}$

The difference between the carpenters, pewterers, and plumbers in Antwerp on the one hand and the shoemakers in Brussels and Mechelen on the other perhaps lies in the fact that the latter were not subject to the vagaries of putting-out systems - masters working autonomously being obliged to continue to create their own independent designs. ${ }^{136}$ Many

I29. Schlugleit, De Antwerpse gond-en zilversmeden, pp. I42, I55, speaks of a "crisis of authority" that would have accelerated in the seventeenth century. See also Alfons Thijs, "Religion and Social Structure: Religious Rituals in Pre-Industrial Trade Associations in the Low Countries", in Prak, Lis, Lucassen and Soly, Craft Guilds in the Early Modern Low Countries, pp. I $57-173$.

I30. Thanks to the work of Mevr. G. Van Hemeldonck, who kindly lent me her notes, we can trace some examples for the gold and silversmiths: CAA, N 3484, 2 March I650; fo. I 22; N 699, 2 May I654; N 699, 30 December 1655; N 699, 3 September 1657; N 492, I6 March I662; Proces S I073 (1662); N 3835 , I August i684; N 657, 10 October 1693.

I3 I. Some examples: CAA, GT 4334, I4 June I497, fo. Iv, art. 2; GT 4335, (copy), fo. Ir; GT 4334, fos 8r-8v; GT 4335, 6 August is I 5; GT 4337, 9 April I686, fos 34-34v (cabinetmakers); GT 4264, 25 June 1705 (plumbers).

I32. CAA, GT 4264, I 2 November I 523; GT 4264, 25 June 1705.

133. For the art sector, see Honig, "The Beholder as Work of Art".

I34. See Salien, “'Op de leest geschoeid””, p. 58.

I35. Danny Pepermans, "Sociaal-economische studie van het schoenmakers- en schoenlappersambacht te Mechelen in de Nieuwe Tijd" (unpublished licentiate thesis, Vrije Universiteit Brussel, 1999), pp. 61-62.

I36. One could also wonder why, in eighteenth- and nineteenth-century Vienna, guild-based 
masters no longer worked independently in their own workshops. Rather, they were involved in wider networks coordinated by merchants or major contractors. ${ }^{137}$ In such cases, they ceased to maintain complete control over the labour process. They only partially manufactured products, or even just assembled parts of them, which had themselves often been designed by others. ${ }^{138}$ Or they perhaps supplied their pieces directly to a mercer or a retailer, who was himself responsible for the product's design. In both cases, product design was increasingly out of reach of guild members.

While apprenticeship contracts rarely included stipulations about designing skills as well, membership lists of several art academies in the southern Netherlands show the registration of large numbers of bricklayers, carpenters, silversmiths, and the like, all of whom wished to learn the basics of drawing. ${ }^{139}$ It suggests that drawing and designing skills indeed became more important over time, and that guild-based mechanisms failed to provide them. In the art academy artisans not only learned "the mother tongue of the labourer", which was important, for example, in construction, but they could moreover profit from the skills and implied prestige of artists.

Summing up, the craft guilds' legitimizing strategies seem to have failed because merchants, mercers, and retailers no longer needed the guilds (or mastership), either for constructing and guaranteeing product quality or for the design of new products. Jean-Jacques Heirwegh, who extensively studied the actual abolition of the trades in the southern Netherlands, asserted that the enemies of the guilds only became successful once

silk weavers, in contrast to women, still had to learn how to make patterns, and why, as a result, girls had to learn three years and boys five or six; Steidl, Auf nach Wien!, p. 25 I.

I37. Catarina Lis and Hugo Soly, "Corporatisme, onderaanneming en loonarbeid. Flexibilisering en deregulering van de arbeidsmarkt in Westeuropese steden (veertiende tot achttiende eeuw)", Tijdschrift voor sociale geschiedenis, 20 (1994), pp. 365-390; and, "Export Industries", pp. II9-I 23 .

I38. In the sixteenth century, Antwerp was a European centre for prints and models. Designers like Cornelis Floris II (I I 4-I575), Balthasar Vanden Bos (alias Sylvius) (I5I8-I580), Hans Vredeman de Vries (I 527-I604), and Hans I. Collaert published prints and models for tableware and ornaments. Apart from these reproducible designs, artisans commissioned product design from sculptors and painters. The most famous was Peter Paul Rubens, but painters like Sebastiaen Vrancx (I573-I647) and Adriaen Van Stalbempt (I 580-I662), and sculptors like Michiel Vander Voort I (I667-I737) and Guillielmus Ignatius Kerrickx (I682-I745) also devised models upon request; Baudouin, Colman, and Goethals, Edelsmeedkunst in België, pp. 19-20. For some examples of these models, see F. Baudouin (ed.), Tekeningen wit de I7de en I8de eeuw. De Verzameling van Herck (s.l., Koning Boudewijn Stichting, s.d.). Even among artisans of the same guild there was a certain "division of labour" with, for instance, (more experienced, gifted or skilled) goldsmiths conceiving models for other goldsmiths; see P. Baudouin, "Verkenning van de Antwerpse edelsmeedkunst in de zeventiende eeuw", in Antwerpen in de XVIIe eeuw (Antwerp, 1989), pp. 387-404, p. 390-391.

I39. Dominiek Dendooven, "De Brugse academie in de achttiende eeuw", 2 vols (unpublished licentiate thesis, Vrije Universiteit Brussel, 1994), p. 263; De Munck, "Le produit du talent". 
merchants and their spokesmen obtained the support of the large, industrial entrepreneurs. ${ }^{10}$ Yet this could only occur once the interests of merchants had first been divorced from the interests of guild-based masters.

In discussions about the guilds' privileges, there was already tension between the craft guilds' perception of the city as a closed and regulated environment on the one hand, and the merchants' view of a free and open urban environment on the other hand, long before the second half of the eighteenth century. In examples of litigation between the Guilds of Mercers and Silversmiths in the first half of the seventeenth century, members of the former guild proposed that Antwerp was no longer a closed city but an openbare koopstad ("open trade city"), just like Paris, Venice, London, and Lyon, where merchants could effectively buy and sell a vast range of commodities at will. ${ }^{1 \mathrm{I}}$ The craft guilds, largely as a means of defining and controlling product quality, remained wedded to the concept of a closed city.

Significantly, the conflict was about defining product quality as well as about the process of controlling mastership. Some mercers had begun to put silver on belts, which was considered to be a unique privilege of the Guilds of Goldsmiths and Silversmiths. Without being masters, these mercers circumscribed the guilds' labour-market monopsony and became directly involved in production, employing journeymen, apprentices, or all kinds of unfree workers themselves. The Guild of Goldsmiths legitimized their reaction by denigrating the inferior quality of the silver used by the mercers.

The most important field of tension was thus not the one between large and small masters but the one between masters on the one hand and merchants and retailers on the other. ${ }^{12}$ Antwerp had inherited an "ideology of commerce" from its golden sixteenth century. Although industrial entrepreneurs realized an "Indian summer" after the closure of the Scheldt in I585, this ideology seems to have prevailed in the seventeenth century both institutionally and ideologically ${ }^{\mathrm{I} 33}$ - most likely discrediting the guilds' claims.

Unfortunately we know very little about the real relationships and

I40. Heirwegh, Les corporations, p. I 10.

I 4. Schlugleit, "De zilverhandel van de Meerse", pp. 4I-44.

I42. "Le voyageur dans les Pays-Bas autrichiens, ou lettres sur l'état actuel de ces pays" [The traveller in the Austrian Netherlands or letters about the present state of these countries] considered the privileges of the traditional guilds to be detrimental, in contrast to the activities of merchants and retailers. The laissez-faire principle was in fact translated into the unlimited activities of vendeurs de tout, faiseurs de rien; Cited in Heirwegh, Les corporations, pp. I08-i I 5. I43. An Kint, "The Ideology of Commerce: Antwerp in the Sixteenth Century", in Bruno Blondé, Anke Greve, and Peter Stabel (eds), International Trade in the Low Countries (14thI6th Centuries): Merchants, Organisation, Infrastructure (Leuven, 2002), pp. 213-222; Van Damme, "Het vertrek van Mercurius. 
conflicts between industrial and mercantile elites. Nor do we fully understand their discourses and representations. It would be interesting, for example, to relate the separation of the interests of masters and mercantile elites to their views on the role of the city. As the success or failure of the craft guilds' strategy was highly dependent upon city walls, the Antwerp craft guilds continued to promulgate their values through local festivals and ritual celebrations, such as processions, festivals for patron saints, and the like, but they faced ever-growing state formation and a concomitant dwindling autonomy of cities.

One hypothesis might be, therefore, that merchants and retailers, who used other means to distinguish their products, had other commitments than the common benefit of the city. Perhaps this helps to explain why guild-based masters in the end lost credibility. In any case, the extent to which craft guilds could defend their powers of regulation and monopoly was itself a product of how other social groups - customers, merchants, and retailers on the one hand and policy makers on the other - valued their overall economic contribution. And this was the battle that the craft guilds lost. Most objections to the guilds came from a "learned culture" of artists, economists, officials, lawyers, and writers, who did not hold handicraft work and its accompanying customs in high esteem. ${ }^{\mathrm{I}}{ }^{4}$ When the Guild of Saint Luke was eventually abolished in 1773 , the argument was that "one cannot disagree on the indecency of confusing the liberal arts with the mechanical arts; the most learned pencil with the coarse brush of the worker who applies colours to a wall or a door". ${ }^{45}$ Handicraft work had lost all its appeal here, while artistic and intellectual skills - in the context of a classicist ideal emphasizing design - seem to have merged.

So it was not labour-market flexibility or industrial capitalism that proved to be fatal for the strategies of guild-based artisans; rather, it was the growing importance of cheaper, fashion-sensitive, and volume production in the context of the shift from the économie de l'offre to the économie de la demande. ${ }^{\mathrm{I}}{ }^{6}$ Until the sixteenth century, the interests of merchants seem to have been compatible with the requirements of craft guilds. When the Guild of Diamond Cutters was established in I582,

I44. Hans-Ulrich Thamer, "On the Use and Abuse of Handicraft: Journeymen Culture and Enlightened Public Opinion in I8th and I9th Century Germany", in Steven L. Kaplan (ed.), Understanding Popular Culture: Europe from the Middle Ages to the Nineteenth Century (New York, I984), pp. 275-300. For the southern Netherlands, see Heirwegh, Les corporations.

I 45 . '[...] qu'on ne sauroit disconvenir qu'il y ait de l'indécence à confondre les arts libéraux avec les arts mécaniques; le pinceau le plus savant avec la brosse grossière de l'ouvrier qui pose des couleurs sur un mur ou sur une porte"; Galesloot, Documents, p. 17. Compare with Alexander Cowan, "Not Carrying Out the Vile and Mechanical Arts': Touch as a Measure of Social Distinction in Early Modern Venice", in Alexander Cowan and Jill Steward (eds), The City and the Senses: Urban Culture since I500 (Aldershot, 2006), pp. 39-59.

146. Cf. Philippe Minard, La fortune du Colbertisme. État et industrie dans la France des Lumières (Paris, I998), p. I60; Maitte, "Le réformise éclairé”, pp. 66-68. 
merchants were supposed to support quality inspections and corresponding guild regulations. ${ }^{147} \mathrm{By}$ the seventeenth and especially the eighteenth century, however, Brabantine cities were confronted with increasing economic activity outside the formal town boundaries, as well as with increasing numbers of faiseurs de rien, vendeurs de tout within the city. In the I770s, Antwerp had one retailer for every sixteen inhabitants. There were, furthermore, a multitude of peddlers who introduced newer and often cheaper products than their guild equivalents from outside. ${ }^{148}$

In this context, masters could no longer defend the need for their terms of apprenticeship, nor their use of master pieces and trademarks. The traditional aura of the independent master became increasingly superfluous because innovation and product design, rather than manufacture and quality control, became the most important asset in the period. ${ }^{\text {I49 }}$ The design of new products could easily be done by the merchants themselves, or could be contracted out to artists. ${ }^{150}$ And concerning the provision of information to consumers, the centre of gravity shifted to the retailers, who functioned as "mediators" between products and consumers, providing information and advice about quality, as well as finishing and even designing products themselves. ${ }^{\text {IS I }}$ From this perspective, the support for laissez-faire understandably coincided with pleas in favour of retailers (e.g. from Adam Smith). ${ }^{\text {IS2 }}$

\section{CONCLUSION}

The craft guilds of Antwerp did not systematically resist the increasing concentration of capital and labour among a smaller number of large

147. CAA, GT 4002, 25 October I582, fos 202r-209r. Cf. Schlugleit, Geschiedenis van het Antwerpsche diamantslijpersambacht, p. I $2 \mathrm{ff}$.

I48. Blondé and Greefs, "Werk aan de winkel", pp. 2 I I-2 I 3; Van Aert and Van Damme, "Retail Dynamics of a City in Crisis", pp. I49-1 50.

I49. Cf. John Styles, "Manufacturing, Consumption and Design in I 8th-Century England", in Brewer and Porter, Consumption and the World of Goods, pp. 527-554; and "Product Innovation in Early Modern London", Past and Present, I68 (2000), pp. I 24-170; Maxine Berg, "From Imitation to Invention: Creating Commodities in Eighteenth-Century Britain", Economic History Review, 55 (2002), pp. I-30.

I 50 . For the gold and silversmiths, see Baudouin, "Verkenning van de Antwerpse edelsmeedkunst”, pp. 390-391, 395; Baudouin, Colman, and Goethals, Edelsmeedkunst in België, pp. 19-20. I5 I. Carolyn Sargentson, Merchants and Luxury Markets: The Marchands Merciers of Eighteenth-Century Paris (London, 1996), pp. I2-13, and ch. 3; and "The Manufacture and Marketing of Luxury Goods. The Marchands Merciers of late I 7 th and I8th-Century Paris", in Robert Fox and Anthony Turner (eds), Luxury Trades and Consumerism in Ancien Régime Paris (Aldershot [etc.], I 998), pp. 99-139; Van Damme, Antwerpse klanten en kleinhandelaars, esp. chs 5 and 6; and Blondé and Van Damme, "Een crisis als uitdaging?", pp. 86-9I.

I 2. Cf. Nancy Cox, The Complete Tradesman: A Study of Retailing, I550-I820 (Aldershot, 2000), ch. I and pp. 176-180. Compare this with the mistrust toward retailing in sixteenthcentury Venice; James E. Shaw, "Retail, Monopoly, and Privilege: The Dissolution of the Fishmongers' Guild of Venice”, Journal of Early Modern History, 6 (2002), pp. 396-427. 
masters. Not only was subcontracting tacitly allowed, sometimes there simply was no ceiling on the number of journeymen per master. Even unfree journeymen could frequently work legally for a guild-based master. Nor did Antwerp craft guilds systematically exclude newcomers. It is true that they adhered strictly to the apprenticeship system, but understanding this system requires differentiating the entrance of new journeymen from the entrance of new masters.

For journeymen, apprenticeship systems could actually serve as a labour-market barrier, distinguishing between free and unfree journeymen, yet it did so only when a "right of preference" existed, which seems to have been rather exceptional. For masters, the principal purpose was not to reduce the number of new masters. At least after 1585 , craft guilds adopted inclusive rather than exclusive strategies. Surprisingly, they were even inclusive towards new masters, suggesting that Kauf- or Verlagsystems were in place. Rather then being "flooded" by the labour market, in any case, most Antwerp craft guilds seem to have experienced a decline in their ability to attract newcomers, to the extent that the very reproduction of work force and masters was jeopardized.

The most important step towards the abolition of corporative regulations was not the liberty for masters to engage more journeymen and apprentices, or to engage unfree journeymen; it was the abolition of master status itself. Both the compulsory apprenticeship term and the master piece served to distinguish masters from merchants and to exclude non guild-based entrepreneurs. While the apprenticeship system distinguished "legal" from "illegal" work, non-guild-based entrepreneurs were invariably suspected of seeking to employ apprentices, journeymen, or even small masters directly as piece workers and thus to bypass "mastership". Compulsory master pieces were meant to prevent merchant-entrepreneurs from entering the trade. Even the obligation for apprentices to live on the premises of their masters should be understood from this perspective. It served to differentiate regular apprentices from those operating outside the guild - either because they worked directly for an illicit entrepreneur or simply because they were such an entrepreneur themselves.

Craft guilds thus created "master status", which in theory had two effects. First, master status installed a labour-market monopsony, preventing outsiders from using the available labour. In the light of possible labour-market shortages, it can hardly be a coincidence that trade ordinances repeatedly prevented outsiders from employing local workers. Second, defining master status defended the masters themselves against proletarianization. Without the existence of "mastership", many masters would simply have been reduced to being mere "piece workers" producing directly for merchants or large entrepreneurs - whether or not on their own premises.

From this perspective, the craft guilds' strategies can be understood 
from a socio-economic point of view, but things become more complicated when trying to understand how these regulations were legitimized. We therefore have to focus upon the product market. As they worked for wealthy people who appreciated status and prestige, most Antwerp guild masters examined here felt the need to present the acquisition of their own products as being prestigious and conveying high status. Guild-based masters and merchants alike were preoccupied with maintaining high levels of product quality, but for the masters, the superior quality of their products legitimized their exclusive status as master craftsmen, which was in turn related to skills. As joining the group required finishing an apprenticeship term and a master piece, the very group identity was related to skills.

In reality however, the corresponding regulations guaranteed neither superior technical ability nor superior product quality as such. Journeymen could often work for guild-based masters without having finished an apprenticeship term, and in any case without having to produce a master piece. Moreover, inspections did not so much guarantee the skill or accuracy with which the final product was made but only warranted certain characteristics of the raw materials used in production. "Seals of approval" distinguished between different qualities of raw materials used and thereby "fixed" or "objectified" product quality by reducing it to one (invisible) element of the product. Declining standardization necessitated this, because product quality became increasingly difficult to assess for customers and thus complicated consumer confidence. For the certification of qualifications, however, it meant that the "trustworthiness" of masters was more important than their technical abilities.

In fact, the craft guilds' definition of skills reflected an important cultural dichotomy of the time. Craft guilds symbolically linked their status to the value of handicraft and manual skills, which had long been prestigious qualities among the urban middle layers of society. From the sixteenth century on, however, a certain tension between the manual and conceptual arts came to the fore: while many artists strove for recognition as "intellectuals", most artisans continued to emphasize the importance of their practical skills. As a result, a status based on skill was extremely tenuous. Along with the stress on the quality of the raw material, it seems to have been a successful strategy as long as the craft guilds targeted market segments with high purchasing power for luxury products. But in the long run this strategy led to their downfall.

It is not entirely clear when these changes got under way, but until the sixteenth century the dominant strategy of most merchants seems to have corresponded with the needs of the guild-based masters. Both groups were content to market their products based on the practical skills that went into producing them and the reliability of the "content" of the raw material. The shift in patterns of consumer spending in the seventeenth and 
eighteenth centuries, however, resulted in these groups having divergent interests. First, as the product market witnessed a proliferation of cheaper alternatives, the intrinsic appeal of many traditional products, in terms of raw materials and the related "trustworthiness", became less important. Second, while guilds continued to reiterate the importance of craft skills and, by default, undervalued design skills, consumer preferences led to an ever greater emphasis on novel design combined with affordability.

In Antwerp, the problem was not the growth of unregulated suburbs, but an increasing quantity of new imported products, especially from France. As a result, local producers first of all faced the competition of mercantile elites and retailers - both in reality and on a representational level. Current research clearly points to the success of retail as the seventeenth and eighteenth centuries progressed (in Antwerp and elsewhere). ${ }^{153}$ Unfortunately, the tensions between production on the one hand and trade or retail on the other are not well understood, but my hypothesis would be that merchant-entrepreneurs and large retailers increasingly circumvented guild regulations in two ways (apart from importing new products): first by directly employing apprentices, journeymen, or masters, and second by designing products themselves perhaps also outsourcing product innovation to the ranks of an artistic community. ${ }^{\text {I5 }}$

Another element that merits additional research is the stance towards the autonomy of cities. The nature of the apprenticeship system and the production of master pieces not only legitimized the masters' claim to superior product quality, it also linked their superior status to a specific urban context. In fact, the dependence of craft guilds on the idea of a closed city signified not only technical prowess but also commitment to the locality, represented by the appropriate trademark, a symbolic knot tying all reciprocal obligations together in a notional unity of producer and community. Further research could examine which changes occurred as a result of processes of state formation, and how they affected the perception of the guilds' claims.

On a representational level, in any case, guild products not only started to seem distinctly old-fashioned, guild strategies were being perceived as a regressive adherence to special pleading and privilege. Most craft guilds simply failed to cope with the gradual shift towards less expensive, more fashionable commodities. Consequently, the focus of attention should shift from economies of scale and labour market changes in the eighteenth century to discursive practices related to skills, competencies, and product quality in a long-term perspective. As appreciation of manual and practical

I 53 . See n. I I4.

I 54. Note also the growing (symbolic) importance of large masters - at the expense of the craft guilds - in De Munck, "Construction and Reproduction". 
skills waned long before industrial capitalism, "deskilling” was not simply the result of technological innovations, economies of scale, stifling managerial control, and the concomitant division of labour. ${ }^{155}$ Entrepreneurs seem to have evaded guild rules not because they wanted to concentrate production further, but because the prestige of masters was no longer necessary as intermediary between journeymen and merchants in a context of low-price competition and product innovation. The centre of gravity was bound to shift towards merchants and retailers.

I 55. Cf. Georges Friedmann, Où va le travail humain? (Paris, 1963); idem, Problèmes humains du machinisme industriel (Paris, 1968); Georges Friedmann and Pierre Naville, Traité de sociologie du travail (Paris, 1964-1970), 2 vols; Harry Braverman, Labour and Monopoly Capital: The Degradation of Work in the Twentieth Century (London, 1974). 